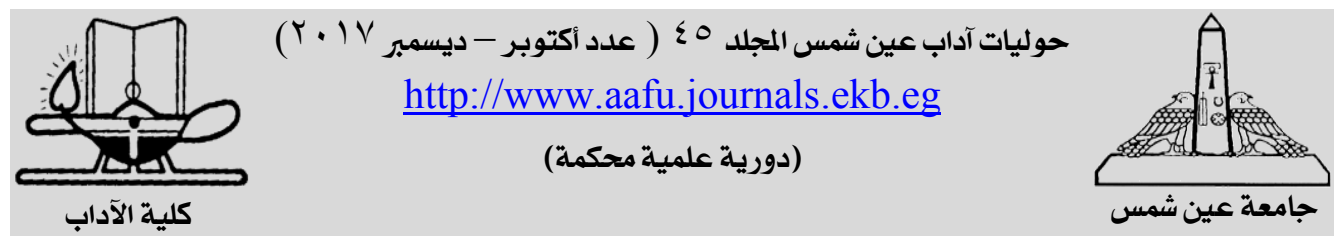

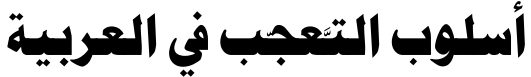

\section{روية جديدة}

* باسم يونس البديرات

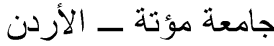

|llinting

بهرف هذا البحث إلى الكثف عن رؤية جديدة في دراسة أسلوب التعجب في اللغة العربية،

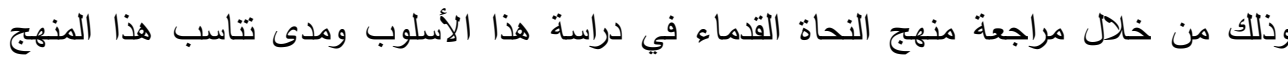
التحليلي مع دلالته، حيث تركّز البحث النحوي القديم لأسلوب التُّجب وما شاكله من الأساليب

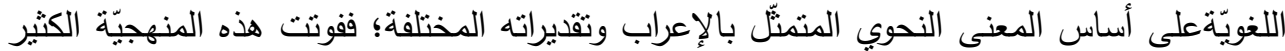

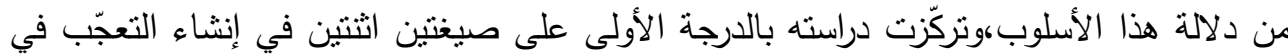
اللغة العربية دون إفراد باب خاص للتعجّب يمكن من خلالده استيفاء جميع الأساليب والتراكيب

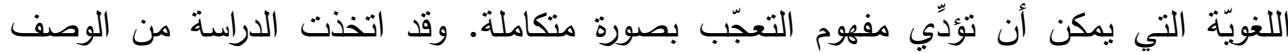
والنحليل منهجاً لها،وستكون الأسئلة الآتية محاورها:

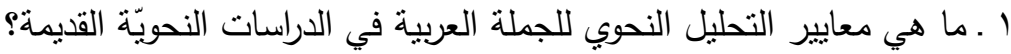

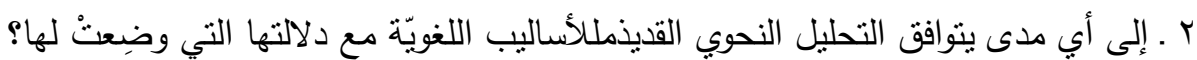

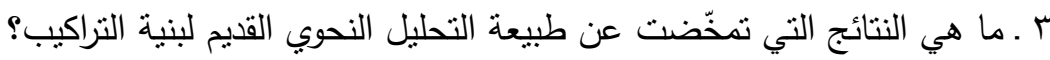

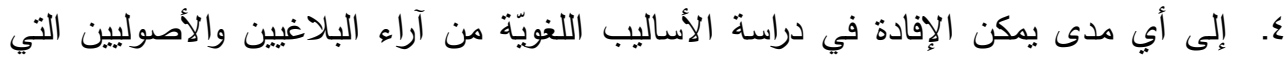

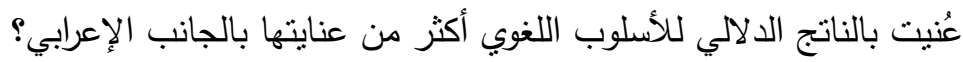


تتاولت هذه الدراسة منهج علماء اللغة القدماء في دراسة الأساليب اللغويّة ثابتة الدلالة في البحث النحوي القديم، وبيان طبيعة هذا البحث الذي ركّزعلى المعنى النحوي (الفاعليّة والمفعوليّة والإضافة...) بصورة تفوق المعنى الدلالي الذي لا يتكوّن من مفردات فحسب، وإنّما من أحداث

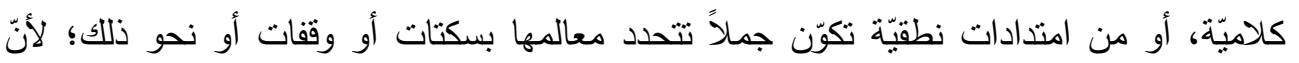
الكلمات ما هي إلاّ وحدات يَيني منها المتكلّم كلامه، ولا يُمكن اعتبار كل منها حدثا كلاميا مستقلا

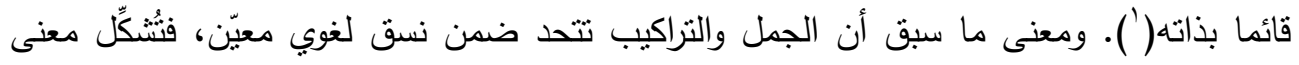
يتجاوز حدود الكلمات مفردة، وهو المعنى الكلّي للتركيب. وفوّت هذا المنهج البحثي في الدرس النحوي القديم على هذه الأساليب اللغويّة: كالتعجّب، والاستقهام، والثرط، والاختصاص، وغيرها، الكثير من دلالتها،ونأى بها عن مظان المعنى المراد

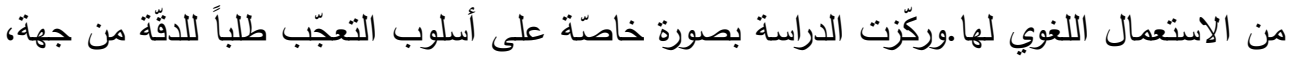
ولغرابة تتاول هذا الأسلوب في الدرس النحوي القديم من جهة أخرى.

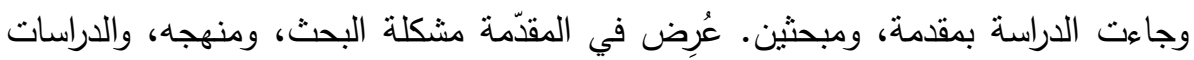
السابقة. أما المبحث الأول فقد عُرض فيه أبرز معايير التحليل النحوي القديم، وأهمّ النتائج التي وني تمخضّت عن طبيعة هذا التحليل. وفي المبحث الثاني عُرِت جملة من الصسائل ذات الصلة بأسلوب التعجّب ومنهج دراسته في التحليل النحوي القديم، منل: مفهومه، وإعرابه، والتراكيب التي تخرج في دلالتها إلى التعجّب في سياقات لغويّة معيّنة. وتتاولت دراسات أخرى أسلوب التعجّب، ومنها:التعجّب بين البصريين ولينهان والكوفيين، لمحيي الدين إبراهيم. والتعجّب من فعل المفعول بين المانعين والمجيزين، لإبراهيم سليمان العايد.والتعجّب صيغه وأبنيته، دراسة لغويّة نحويّة مقارنة، لجميل علوش، وصين وليخ التعجّب بين البصريين والكين والكوفيين

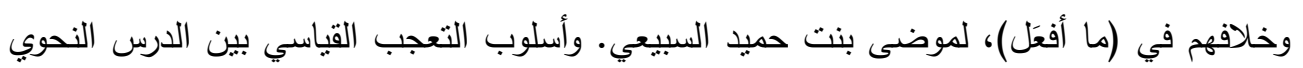
والاستعمال القرآني،لعلي مدلل. ولعلّ ما يميّز هذه الدراسة عن غيرها من الدراسات السابقةتركيزها

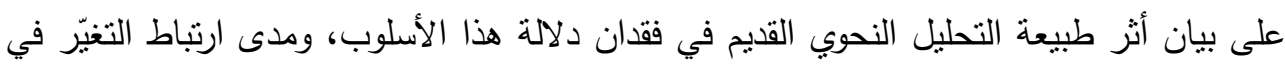

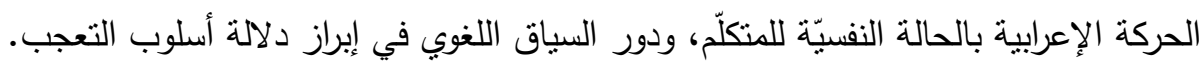

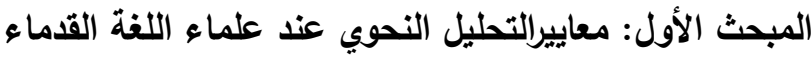

كان لعلماء اللغة العربية القدماء إسهامات متميزة في دراسة اللغة العربيّة على جميع

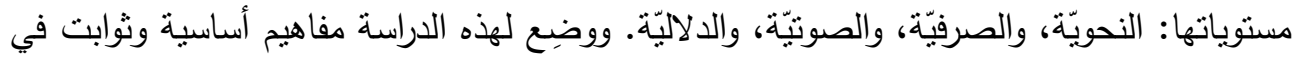

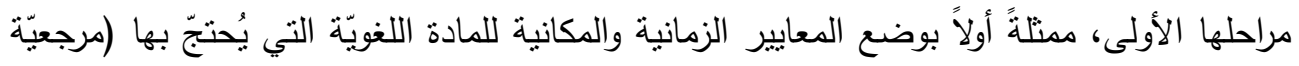

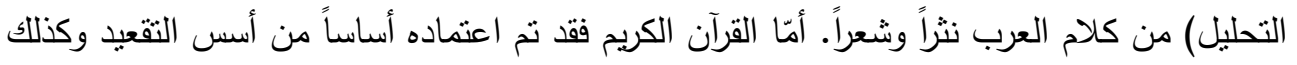
قراءاته. وأمّا الحديث النبوي الثريف فقد دار حوله في مسألة الاحتجاج جدل مستقيض بين 
الدارسين والباحثين، ورجّح معظمه عدم الأخذ به في مسألة الاحتجاج؛ لعلّة روايته على

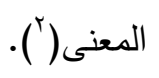

وكانت الجملة من بين ما عني به النحاة القدماء في دراستهم للغة العربية، فحظيت بقدر

وافر من الدراسة والتحليل، فكان لهم الجها العظيم المشكور في هذا الجانب. والجملة-عند النحاة -

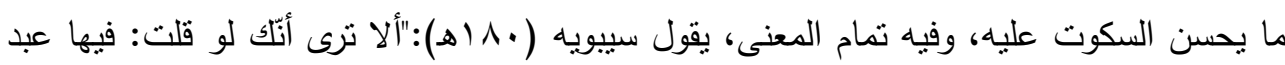

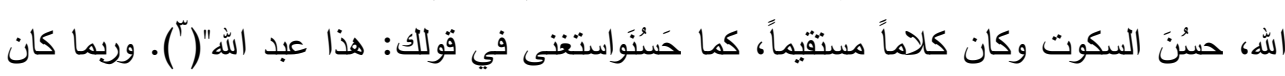

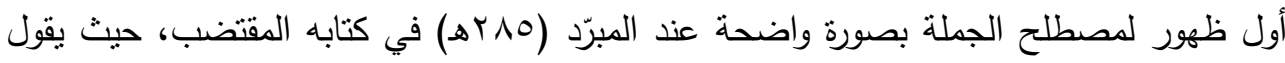

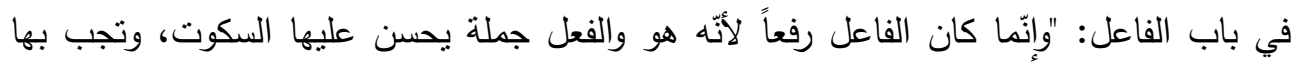

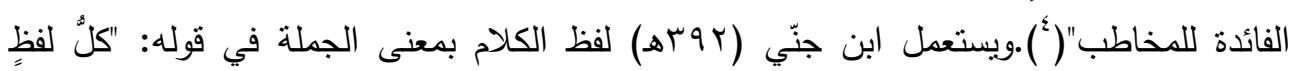

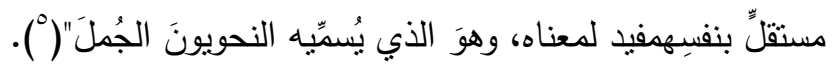

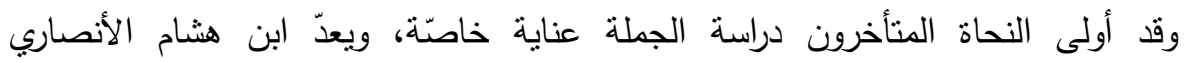

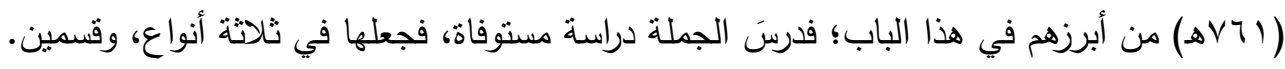

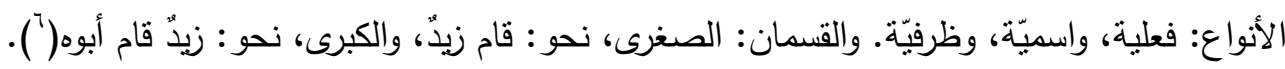

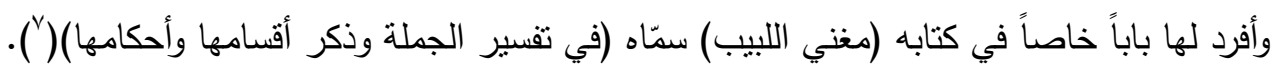

وعلى هذا الأساس حُدّد مفهوم الجملة عند النحاة، وبدأوا بوضع الأسس والمعايير التي لني

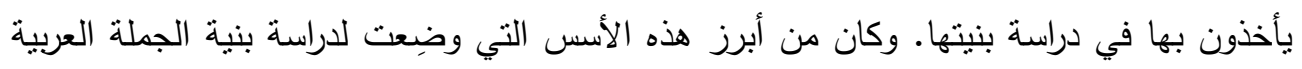

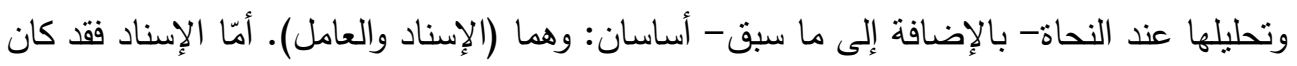

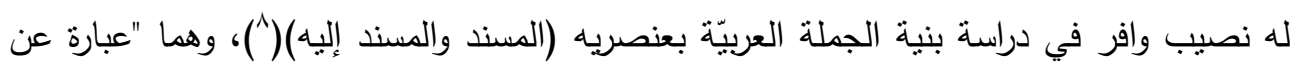

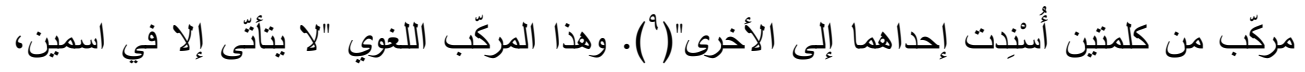

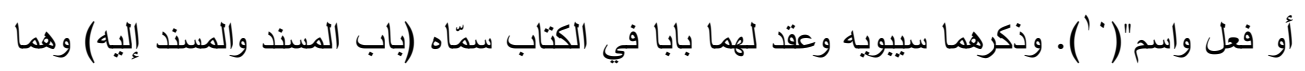

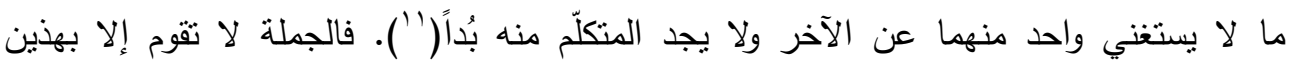

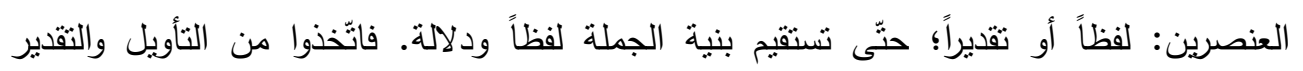

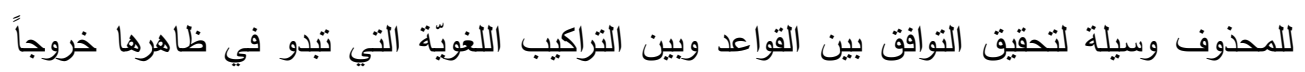

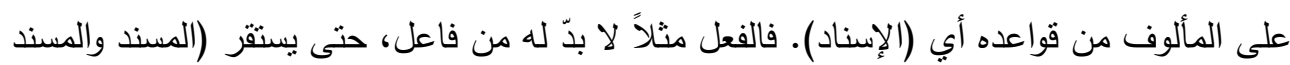

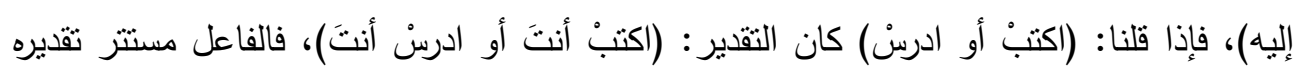

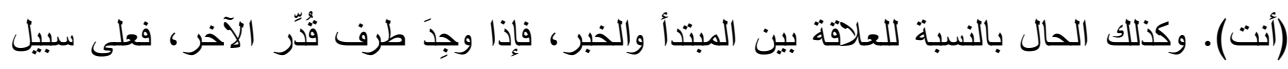

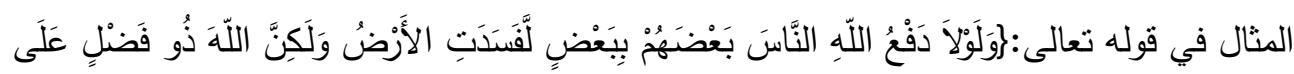

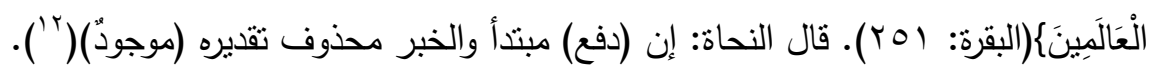

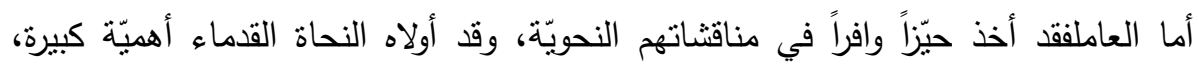

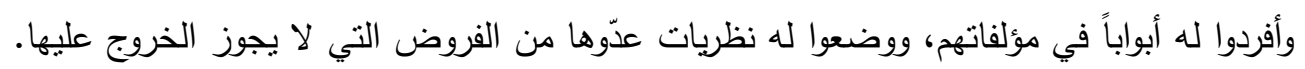


يقول ابن خلدون في ذلك:"تثّ رأوا تغيّر الدلالة بتغيّر حركات هذه الكلمات، فاصطلحوا على تسميته

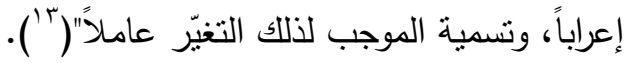

وأول ذكر للعوامل في الدرس النحوي القديم عند الخليل بن أحمد فيما ينقله عنه سيبويه بقوله: "هذا باب الحروف الخمسة التي تعمل فيما بعدها كعمل الفعل فيما بعده ... وزعم الخليل أنها

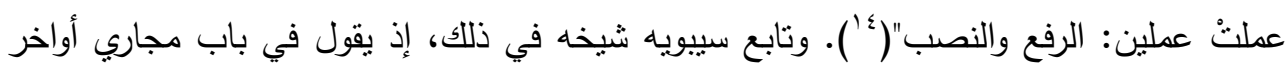

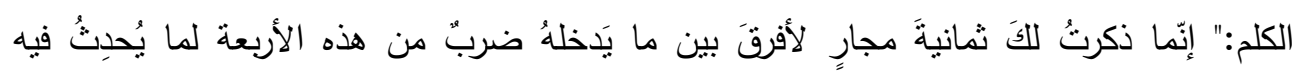

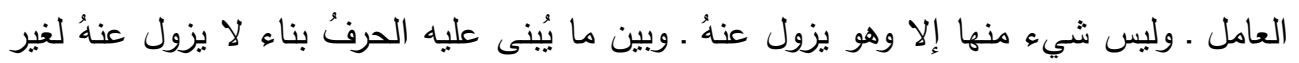

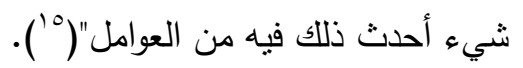

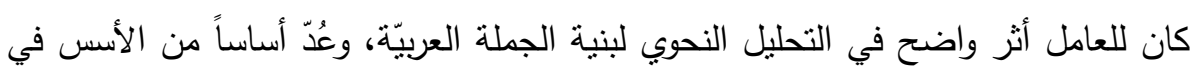

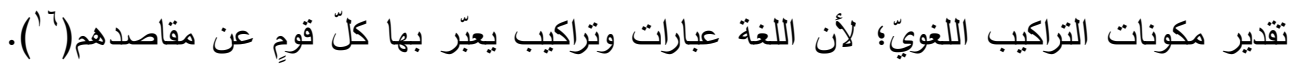

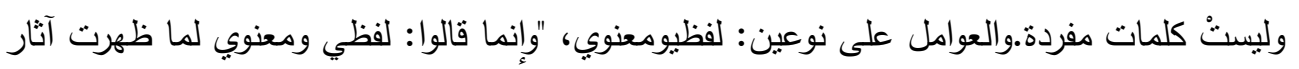

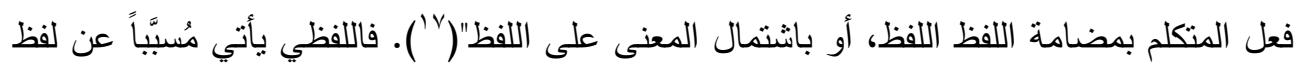

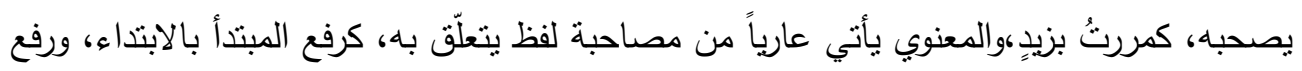

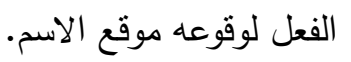

ونتيجة لاهتمام النحاة بالعامل فقد وضعوا له جملة من المعايير كان لها الأثر الواضح في

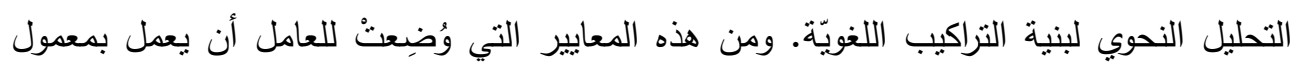

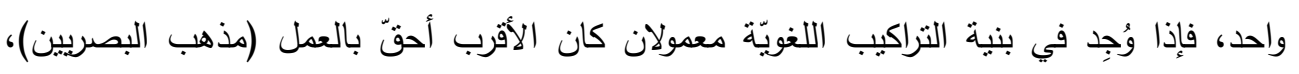

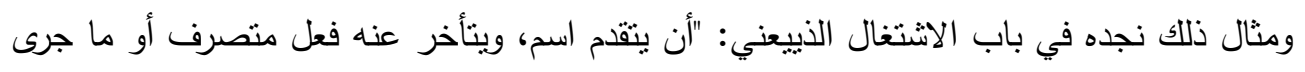

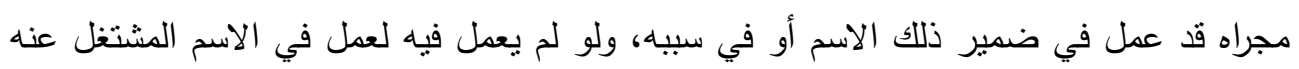

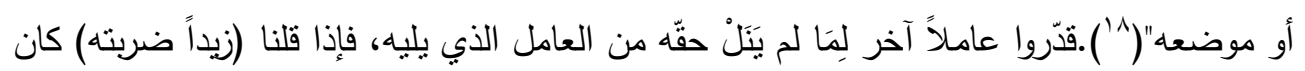

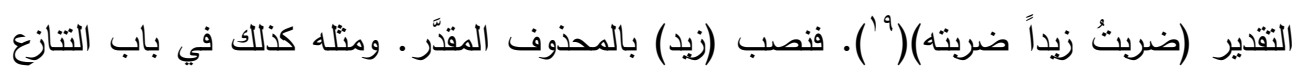

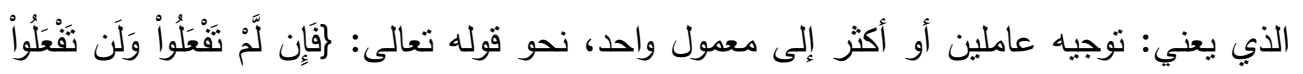

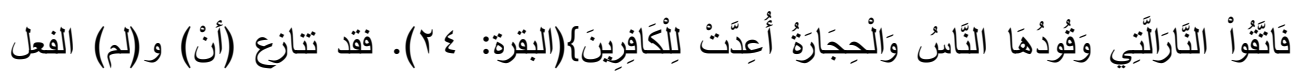

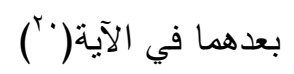
ومن المعايير الأخرى للعامل الاختصاص، فقد كان لهذا المعيار أثز واضح كذلك في

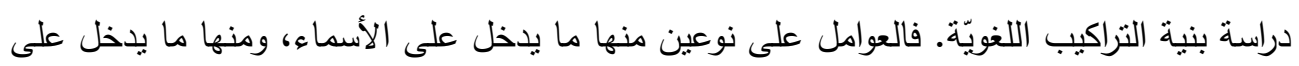

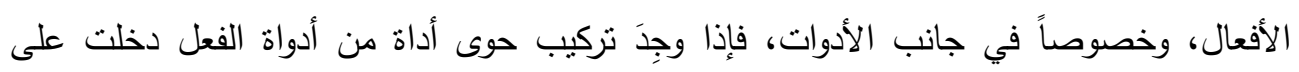

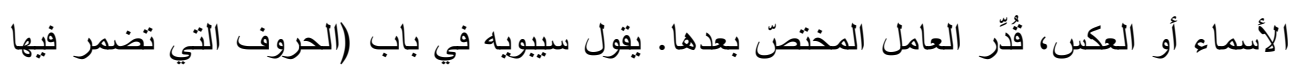

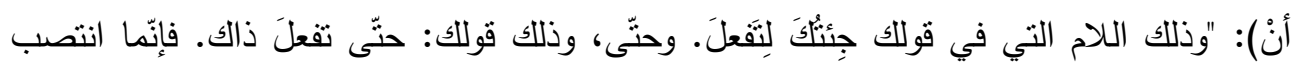

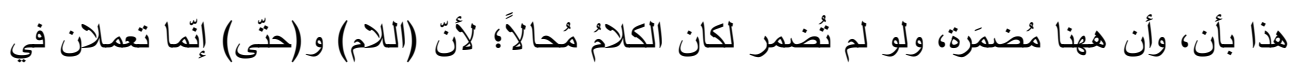




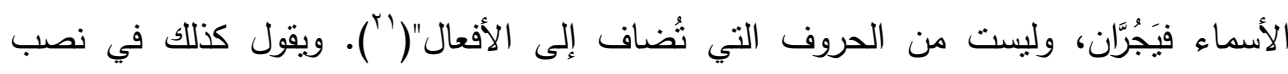

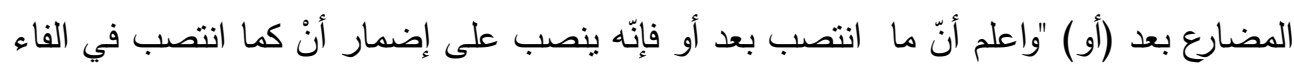

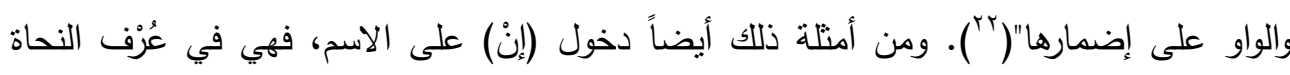

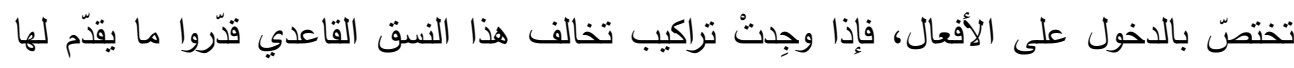

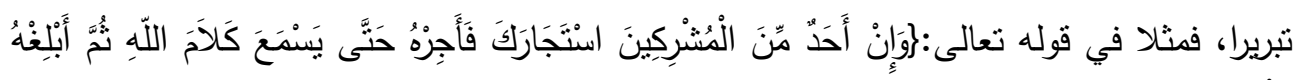

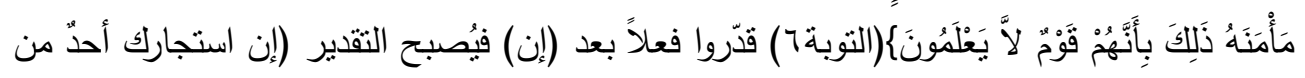

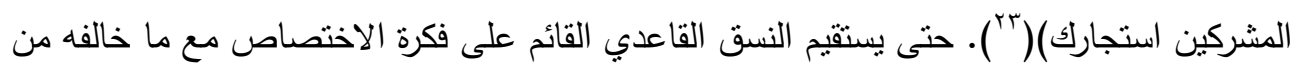
التزاكيب الفصيحة.

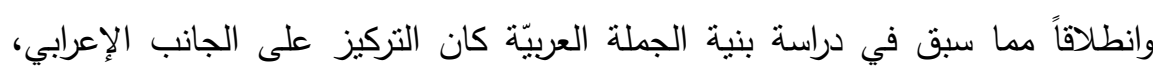

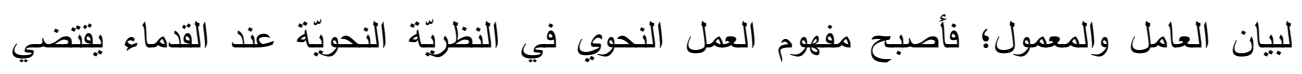

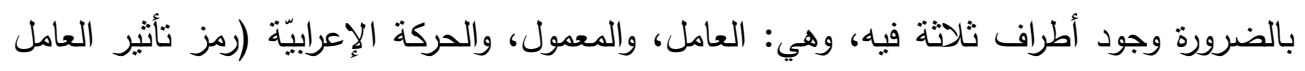

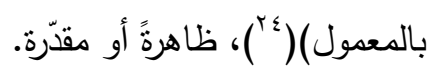

ونحن وإن كنّا نتقق مع النحاة القدماء في اهتمامهم بالعامل، حيَّث قدّم تبريراً منطقياً يقبله

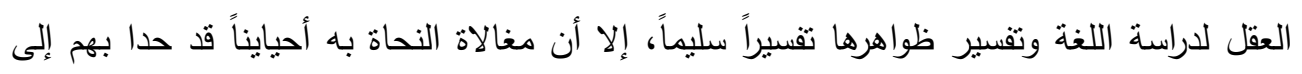

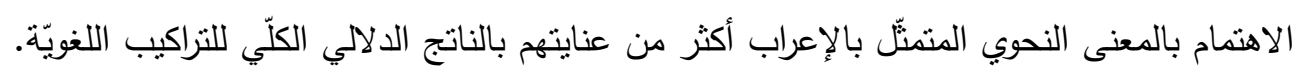

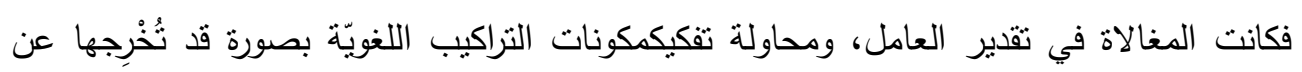

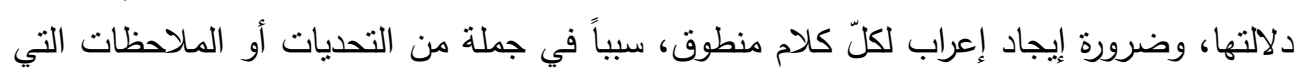

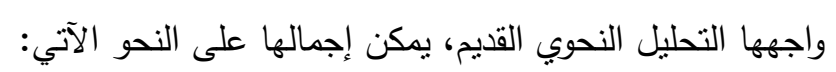

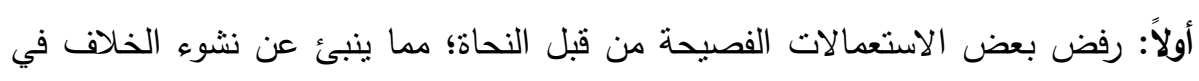

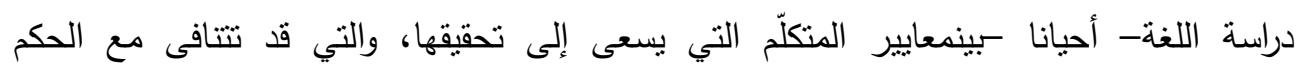

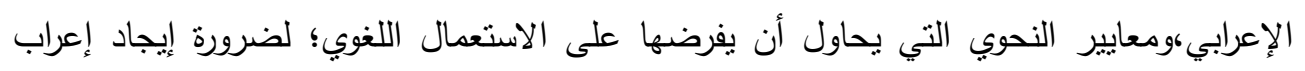

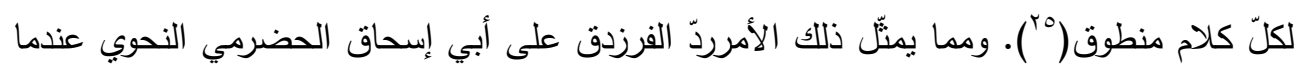

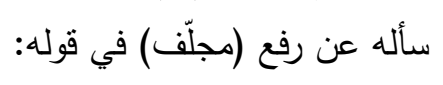

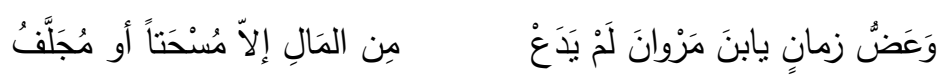

فردَّ الفرزدق - على السؤال الذي ينبئ عن اعتراض من النحوي على طريقة الاستعمال

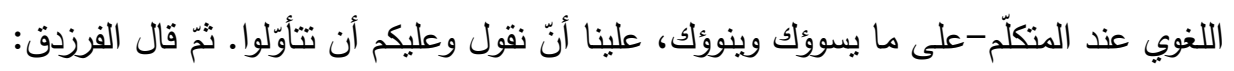

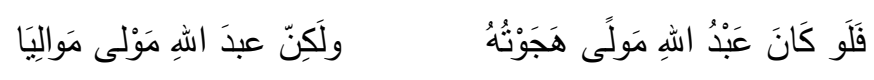
فقال له عبد الله: أردتَ أن تهجوني فلحنت أيضاً (ب7).يقصد قوله (مواليا) فالقاعدة النحويّة

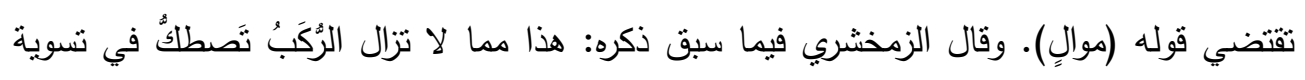


إعرابه(YV)، ويقصد رفع (مجلَّف). وجاء في العقد الفريد: أن النحوبين قد أكثروا الاحتيال لهذا

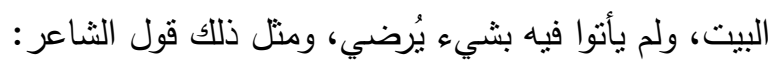

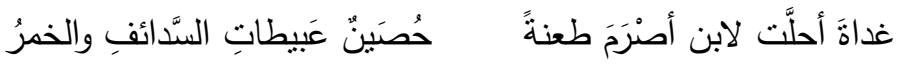

فنصب (عبيطات السدائف) ورفع (الخمر) وهي معطوفة عليها، وكان وجهها النصب(مَ').

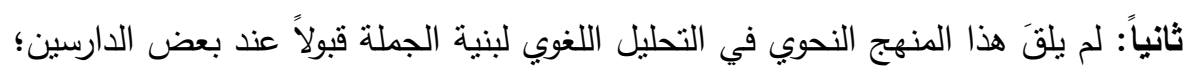

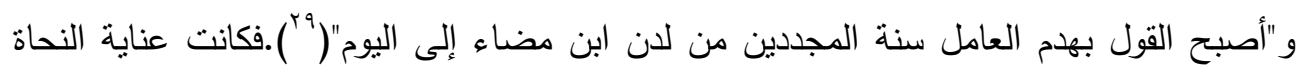

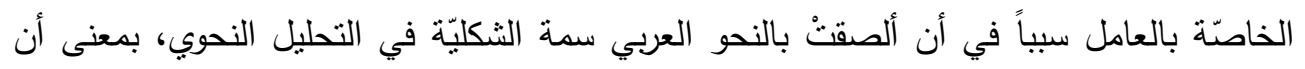
التحليل النحوي قدأعطى أولويّةللفظ على حساب الدلالة.ومن هؤلاء الدارسين الدحدثين إبراهيم

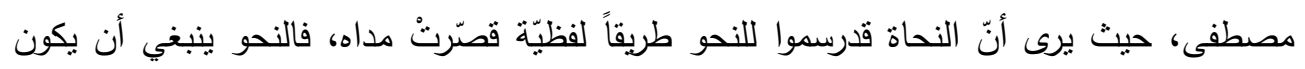

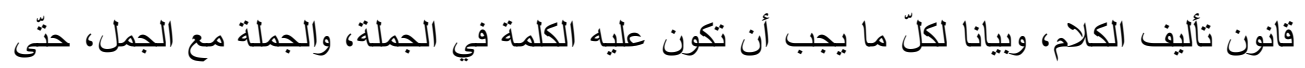

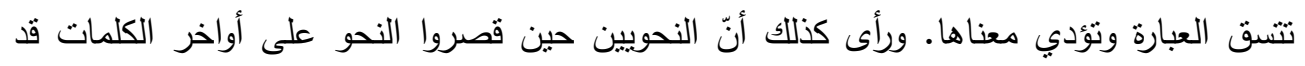

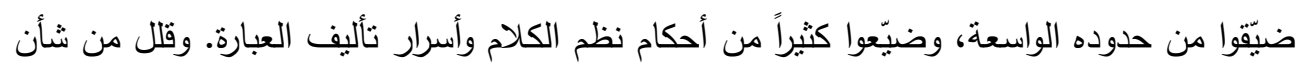

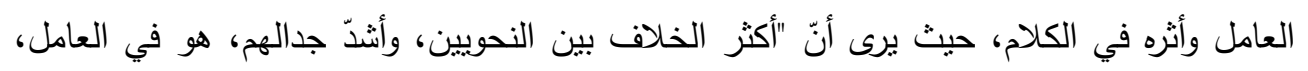
ولو أنّهم (النحاة) وضعوا نظريتهم على أصل صحيح لقلّ خلافهم وتقاربت آراؤهم"( “بَ). فقد أصبح يُنظر إلى المنهج النحوي السائد قديماً في دراسة الأساليب اللغويّة وتدريسها على فلى

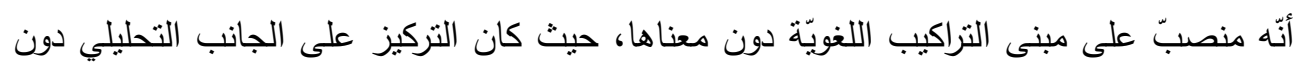

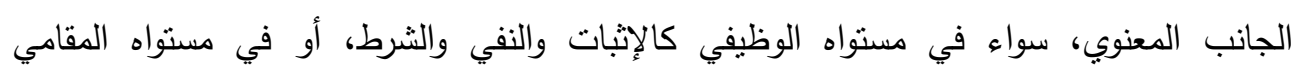

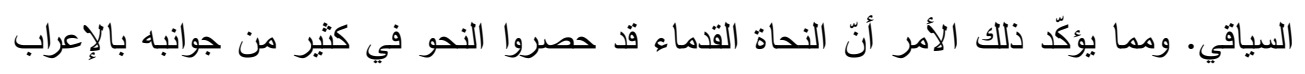

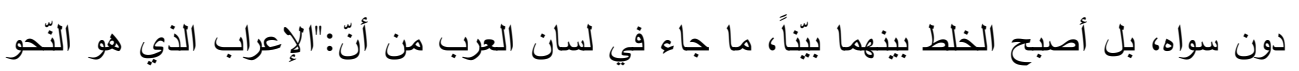

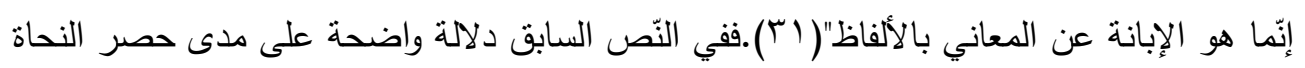
القدامى للنحو في جانب واحد منه، وهو الإعراب، وإن كان الإعراب جزءاً من النحو لا النحو كلّه.

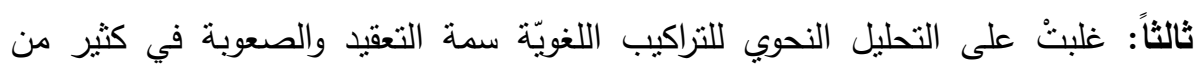
الأحيان؛ فنتكّلت نظرة الصعوبة منه، إلى حدّ النفور . ومما يوضتح ذلك على سبيل المثال إعراب

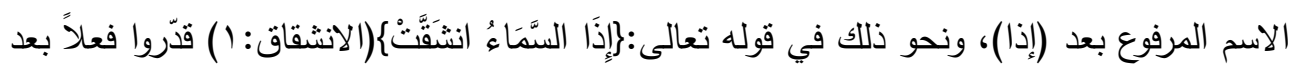

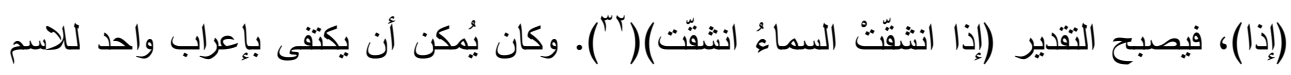
في منل هذا الموضع على أنّه مبتدأ مرفوع قياساً على أي اسم مرفوع تبدأ به الجملة الاسميّة. يقول

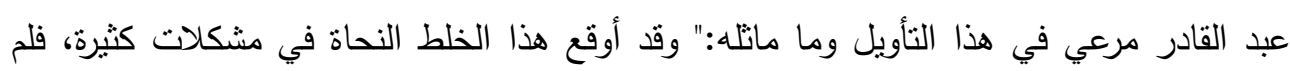

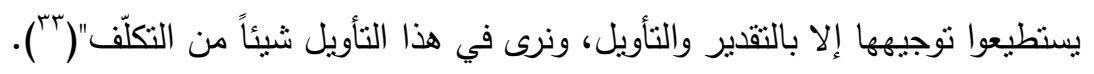




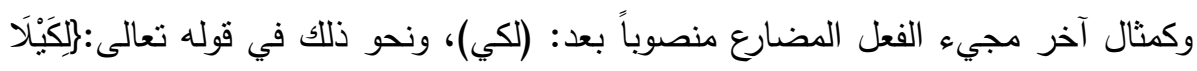

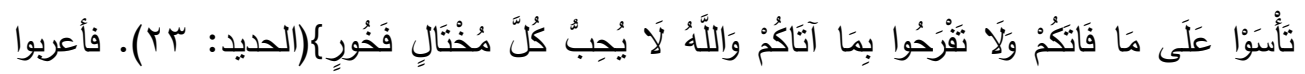

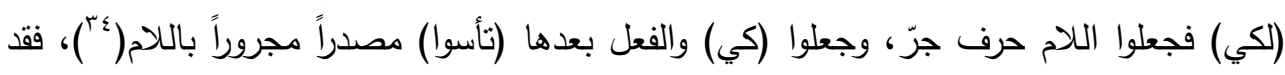

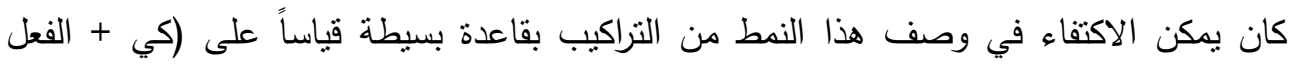

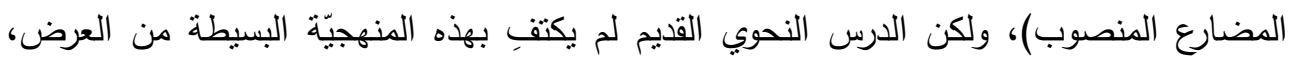

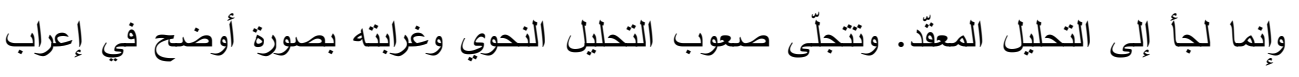

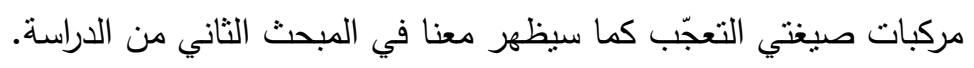

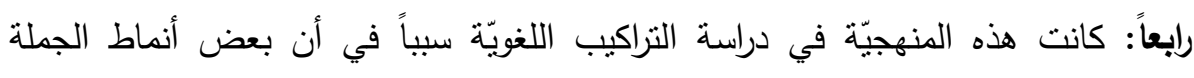

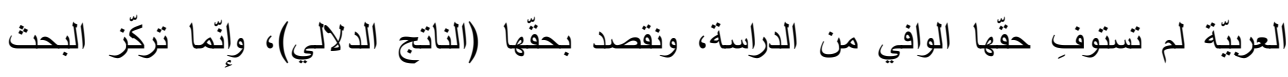

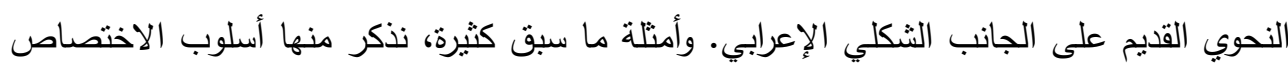

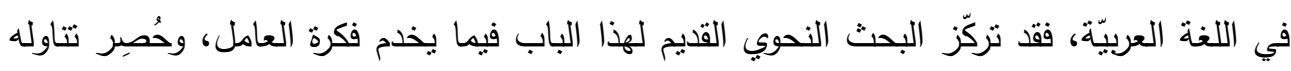

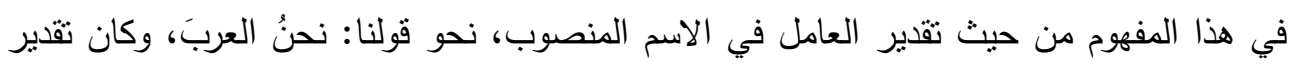

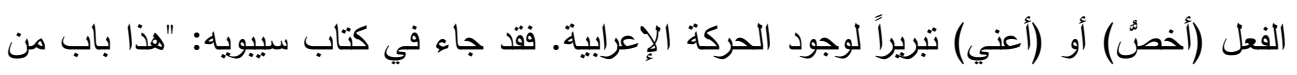

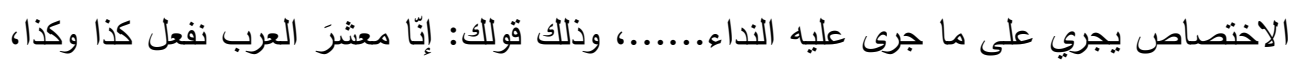

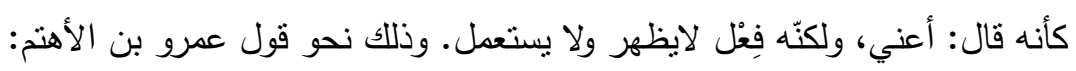

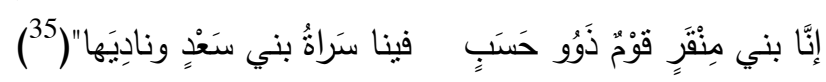

وقد استقر عند المتأخرين من النحاة أن المنصوب على الاختصاصهو: اسم معمول

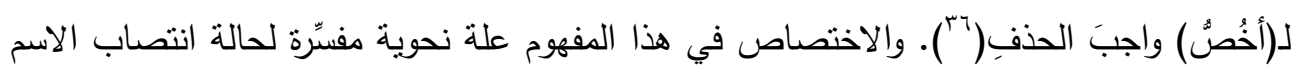

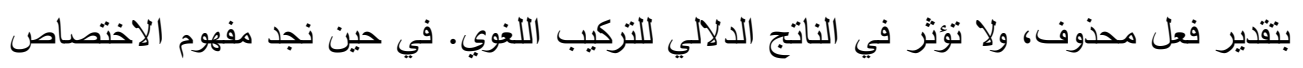

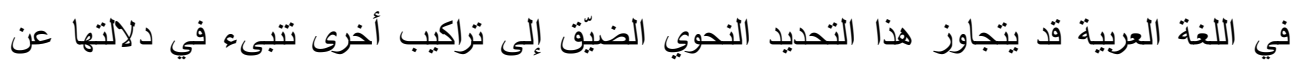

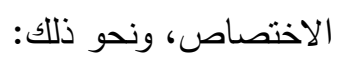

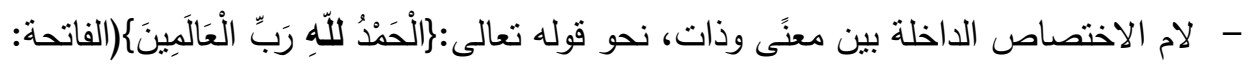
. (r - المخصوص بالمدح أو الذم، نحو قولنا: نعمَ الرجلُ خالدّ. وبئس الرجلُ زيدّ. - النعت المقطوع، نحو قولنا: أكرمتُ عمرَ القويُّ.

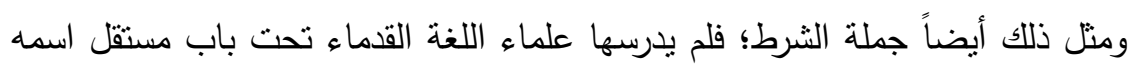

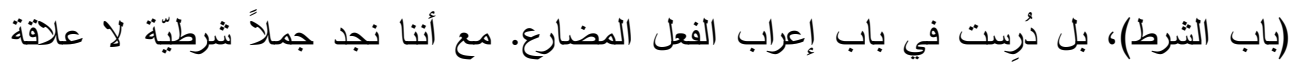

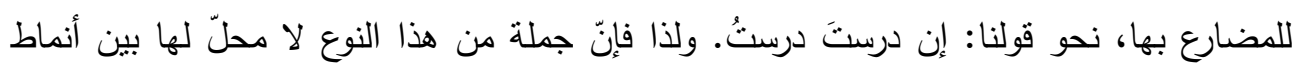

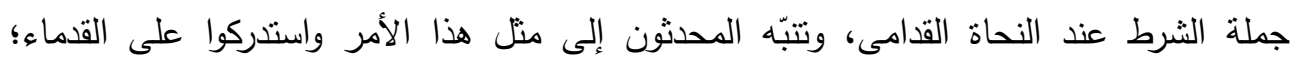

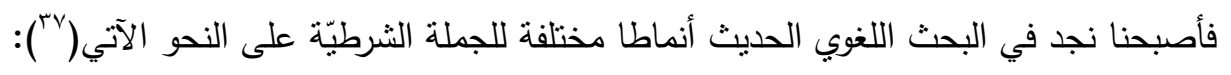




\section{- إنْ + فعل ماضٍ + فعل ماضٍ. نحو : (إنْ قاتلونا قاتلناهم).} - إنْ + فعل ماض + فعل مضارع. نحو: (إن افترقتم لم تجنمعوا بعدها أبداً).

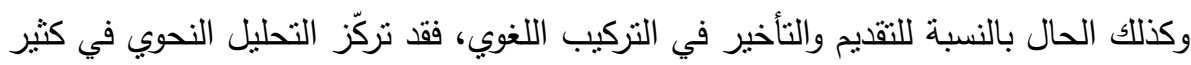

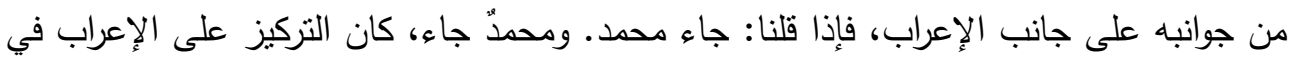

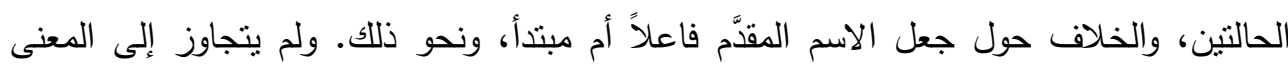
الدلالي حدود ما صرّح به النحاة في تعليلهم لفوائد النقيم في الكلام على فائدة (الاهتمام والعناية).

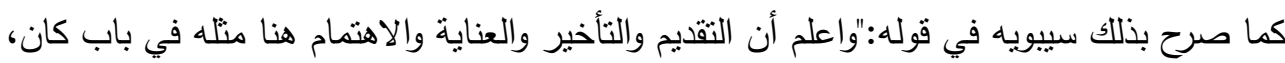

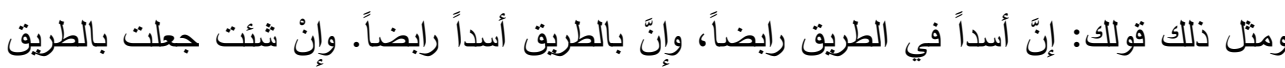

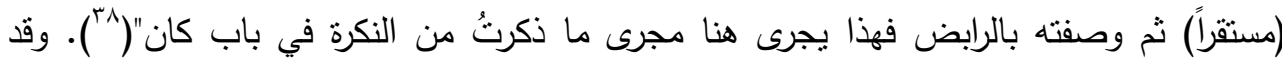

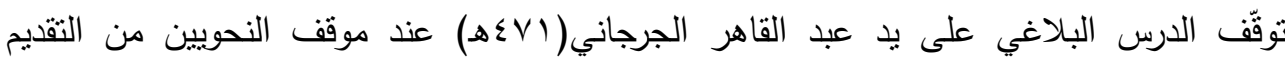

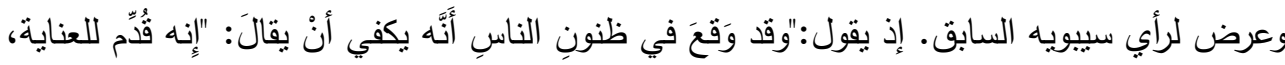

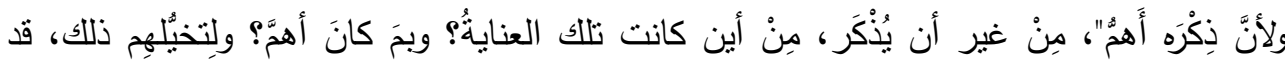

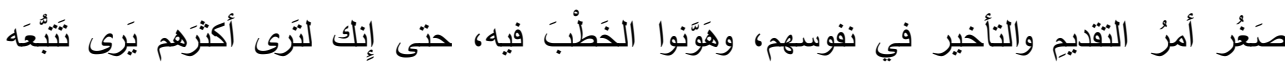

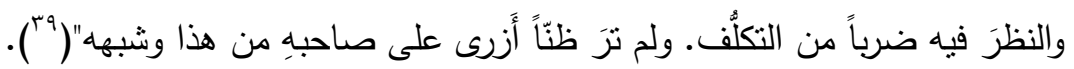

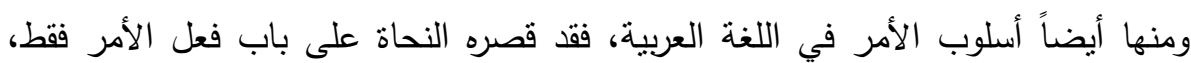

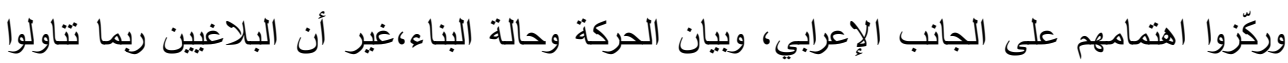

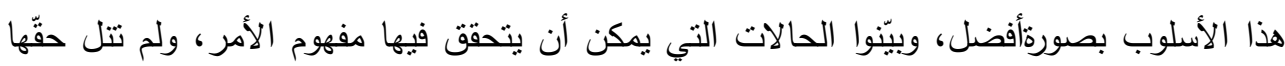

$$
\text { في البحث بصورة تكامليّة في باب الأمر ، ومنها: }
$$

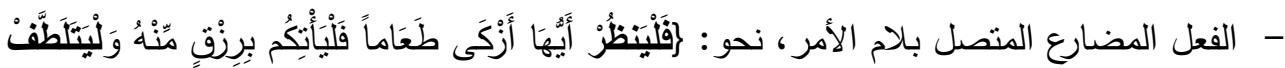

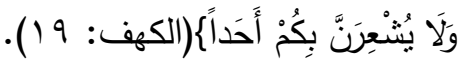

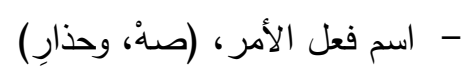

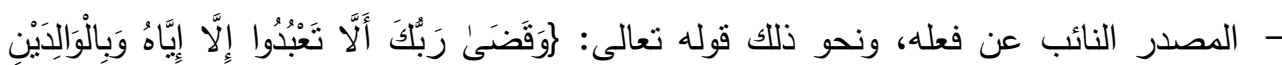

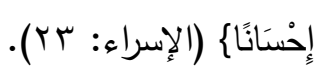

وكذلك الحال بالنسبة لاراسة الأزمنة في اللغة العربيّة، فلم ثُرس دراسة مستقلّة مستوفاة،

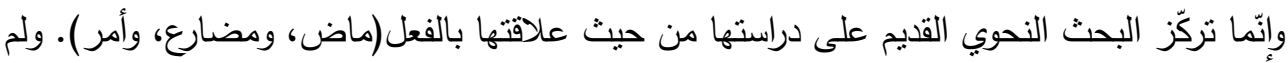

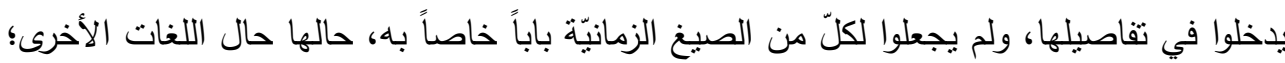

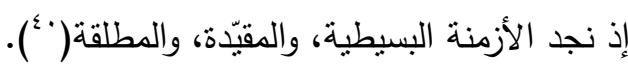

خامساً: وهو أمر برتبط بما سبق، إذ أصبحتْ الدراسات النحويّة الحديثة نستقي أنظارها - رأرأ

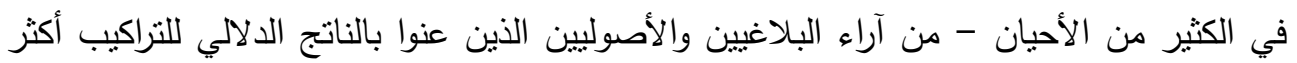


من عنايتهم بالجانب الثكلي المتمثّل بالحركة الإعرابية وما تؤديه من معانٍ نحويّة. وبرز هذا

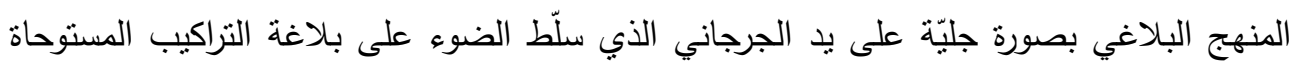

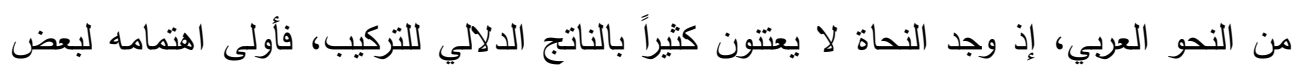

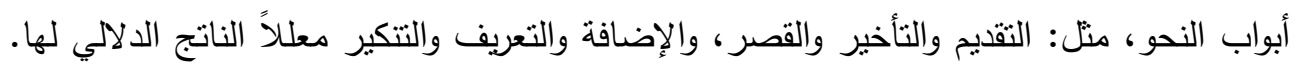

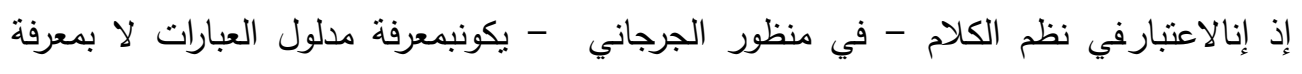

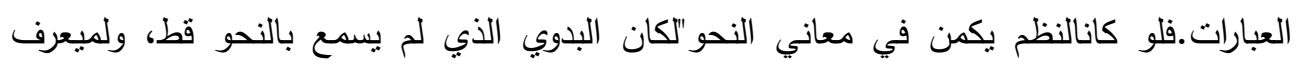

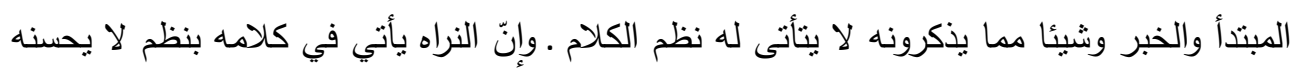

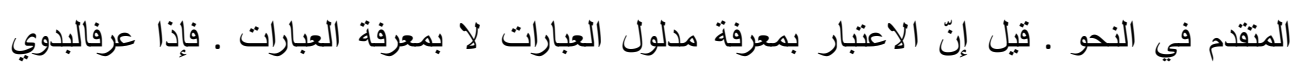

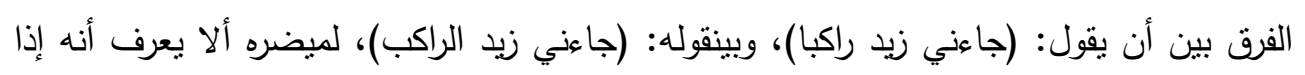

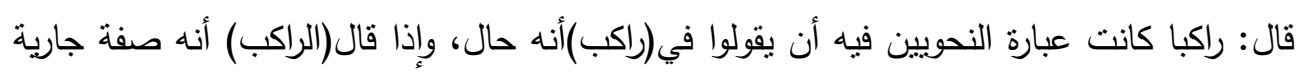

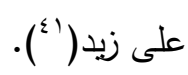

وانطلاقاً من رأي الجرجاني السابق أخذتْ الدراسات النحويّة الحديثة توسّع مجال دراسة

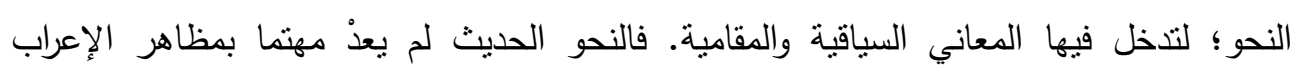

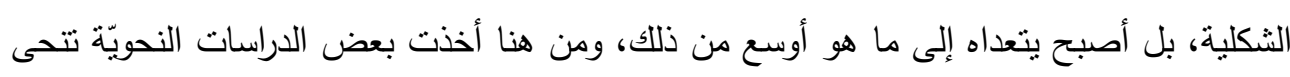

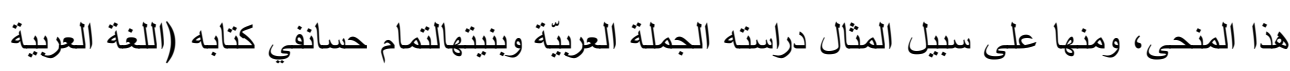
معناها ومبناها)، فقد أقام حدود دراسة الجملة في ضوء فكرة التعليق التي أفادها من نظرية النظم

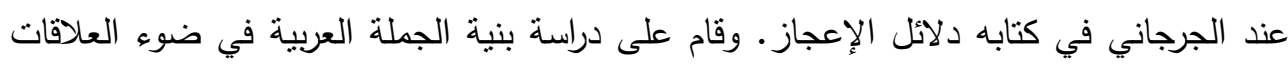

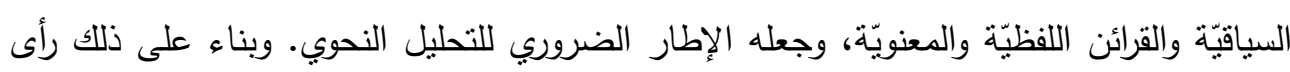

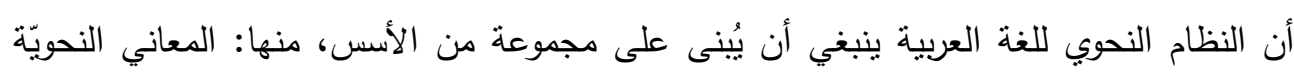

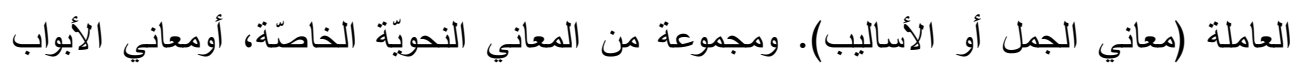

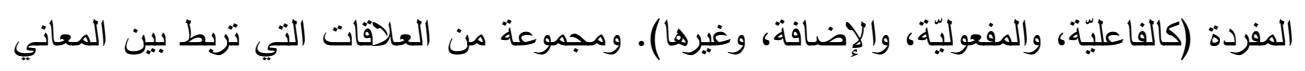

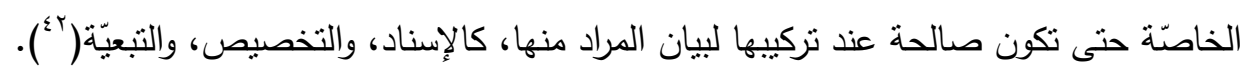
والخلاصـة أن المنهج النحوي الحديث في معظم دراسته للغة مال إلى جانب الوصف في في الكي

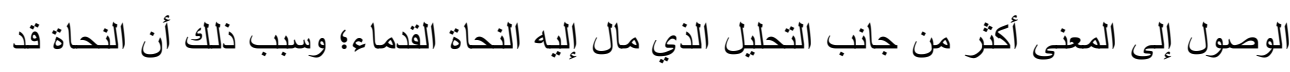

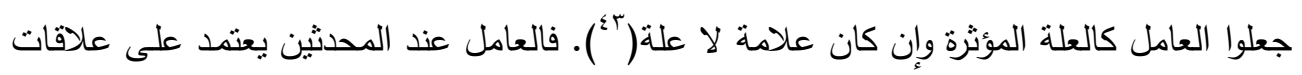

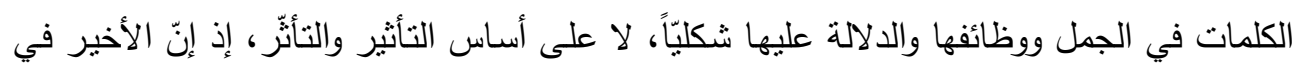

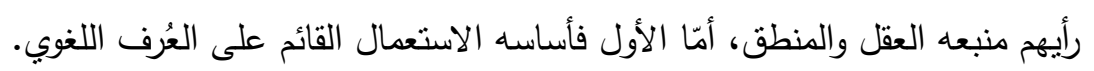
المبحث الثاني: أسلوب التعجّب لقد كان التعجّب أوّل أبواب النحو دراسة على يد النحاة الأوائل، وبالذات أبو الأسود

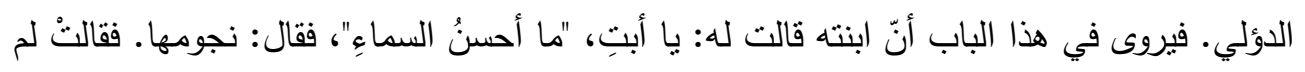


أرد أبيّ شيء منها أحسن، وإنّما تعجبتُ من حُسنها. فقال: إذاً قولي: "ما أحسنَ السماء!" فوضع

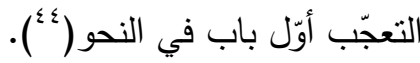

فكانت بداية التحليل النحوي عند القدماء بالتعجّب. فاتّم تحليل هذا التركيب بالصعوبة والغرابة والتجزئة؛ لعلّة مفادها ضرورة إيجاد إعراب لكلّ كلام منطوق، مما بعني ضرورة التركيز

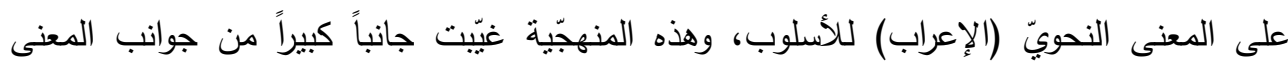
الدلالي للأسلوب، الذي قد لا يرتبط بالمعنى النحوي قدر ارتباطه بجوانب أخرى كما سيظهر في

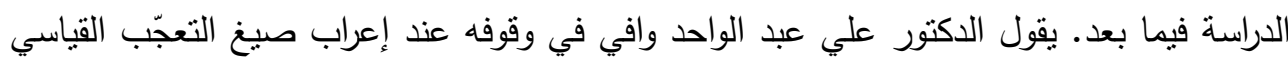

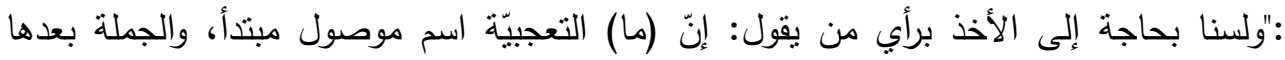

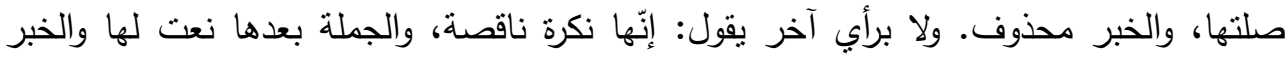

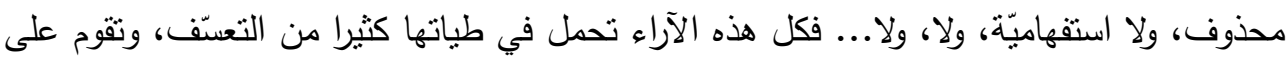

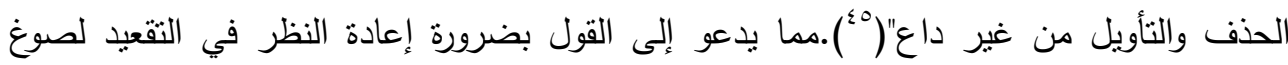

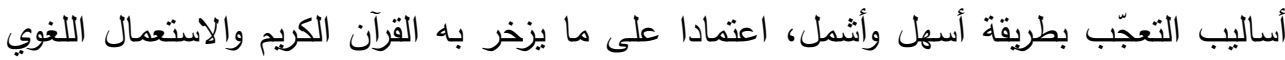

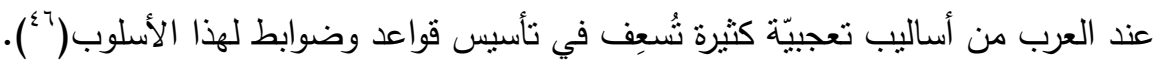

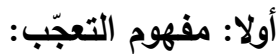

لقد ارتبط المفهوم اللغوي للتعجّب في المعاجم العربيّة بـ (العُجْب والعَجَب)، بمعنى: إنكار ما

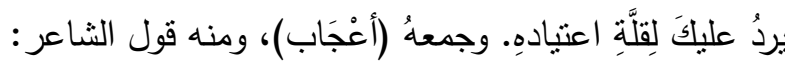

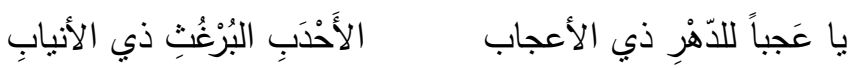

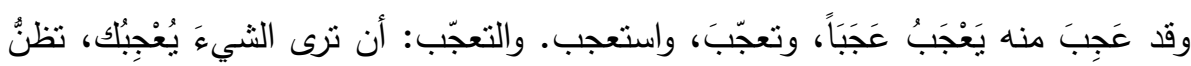

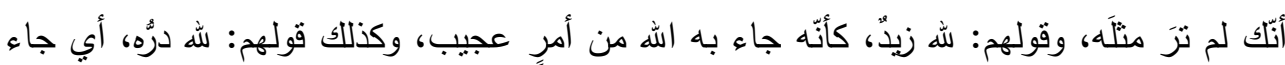

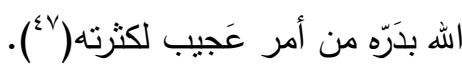
والتعجّب قد يدلّ على محبّة الفعل، ونحو ذلك في الحديث: (عجب ربّك من شاب ليس

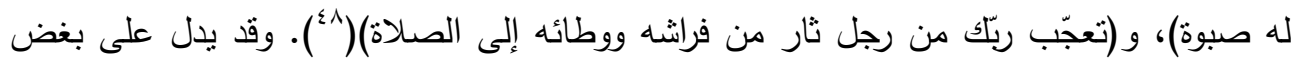

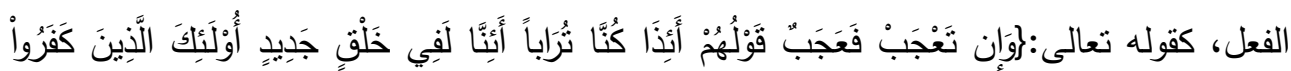

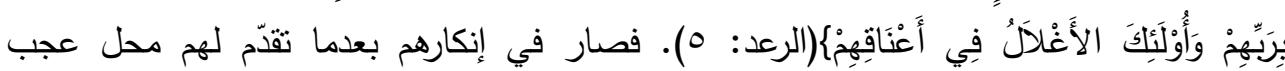

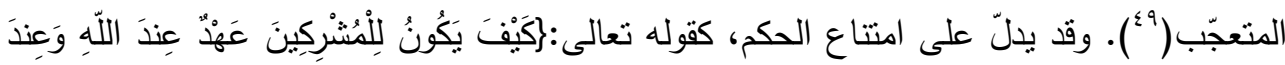
رَسُولِهِيُ (التوبة: V). قال القرطبي :"كيف هنا للتعجّب، كما تقول كيف يسبقني فلان، أي: لا ينبغي

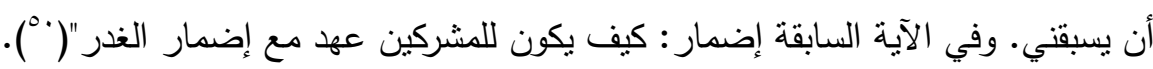
أما عن مفهوم التعجّب في الدراسات النحويّة، فيعني: الدهشة، والاستعظام بزيادة في وصف الفاعل خفي سببها، وخرج بها المتعجَّب منه عن نظائره، أو قلّ نظيره، ونحو ذلك قوله لهابه 


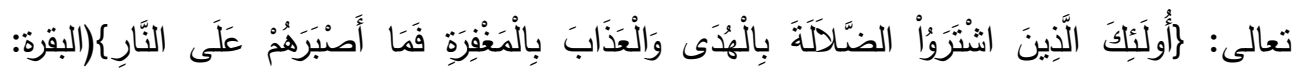

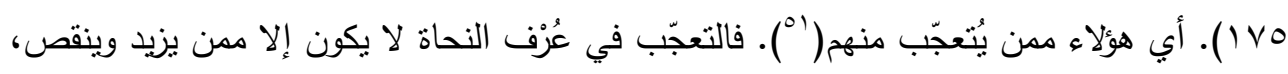

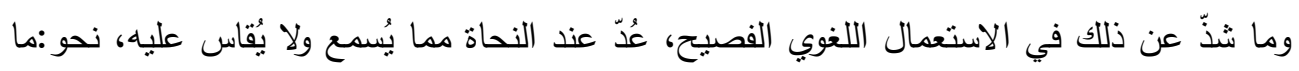

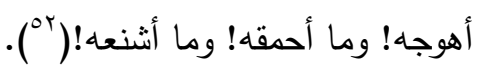

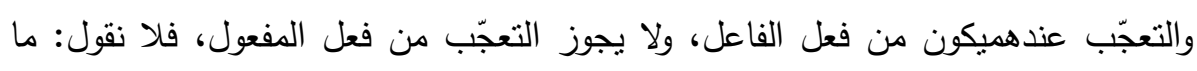
أضربَ زيداً، إذا تعجبتَ من الضرب الذي أوقع به، وهو مذهب الجمهور،خالفه ابن مالك، وأجاز

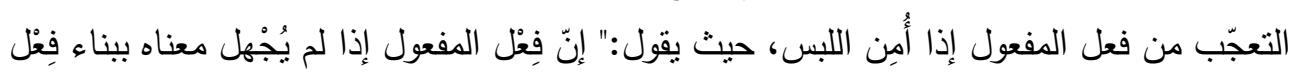

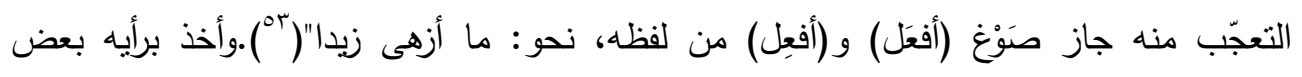

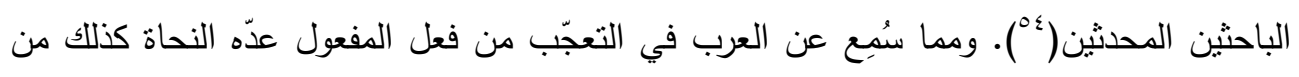

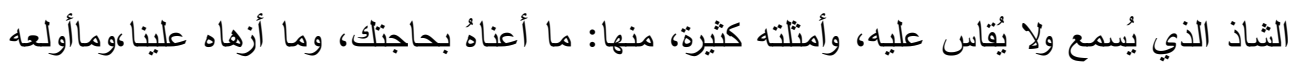

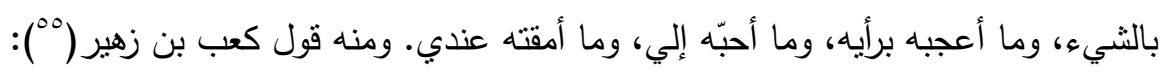

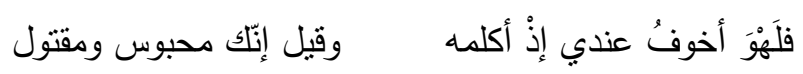

ويتضح من العرض السابق لمفهوم التعجّب بنوعيه (اللغوي والنحوي) أنّه يتضمّن أمرين، وهما:

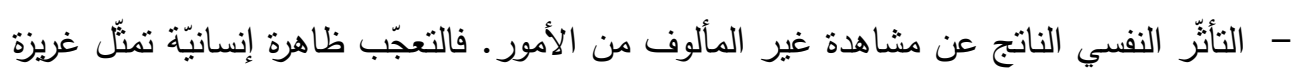

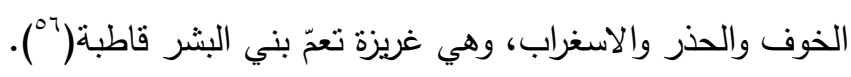

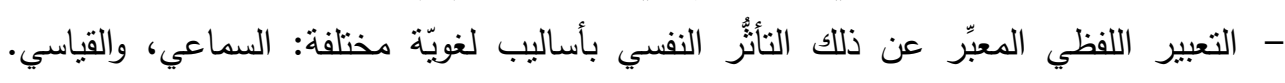

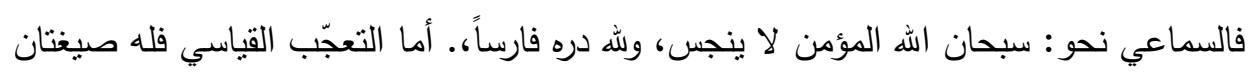

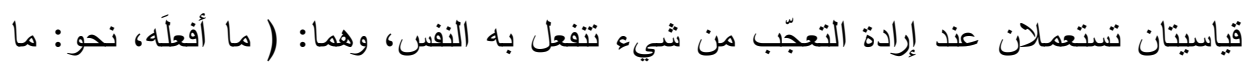

$$
\text { ثانياً: شروط فعل التعَ زيداً!)، و (أفعلْ به، نحو : أحسنْ بزيدٍ!). }
$$

حدد النحاة لصياغة التعجّب من الفعل جملة من الثروط يجب تواجدها فيهمجتمعةً، فإذاذا

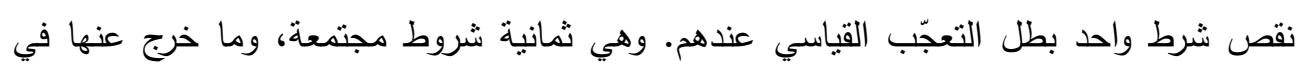

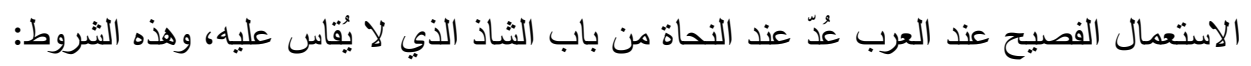

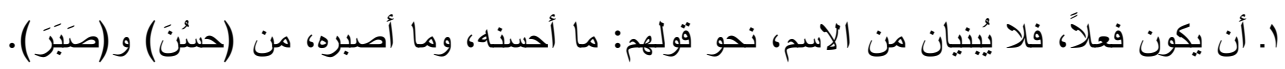

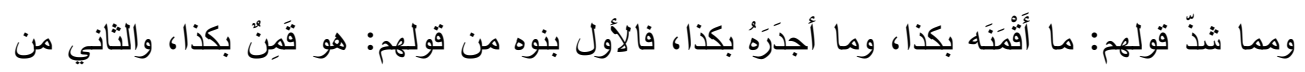

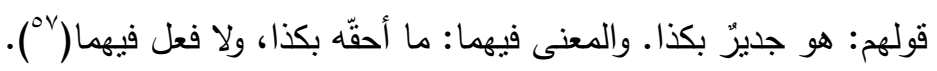

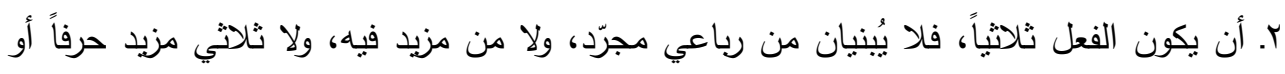

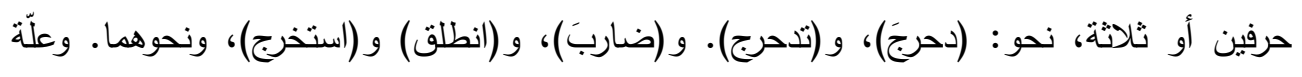

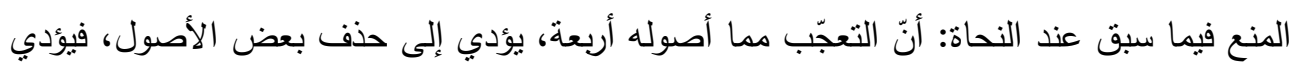

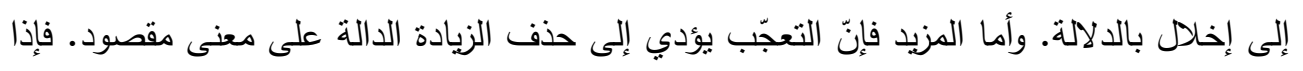


تعجبنا من (ضاربَ، وانطلقَ، واستخرج)، فقلنا: ما أضربه، وما أطلقه، وما أخرجه؛ لفاتت المشاركة

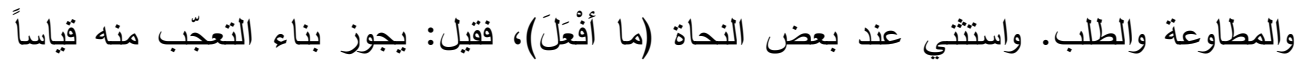

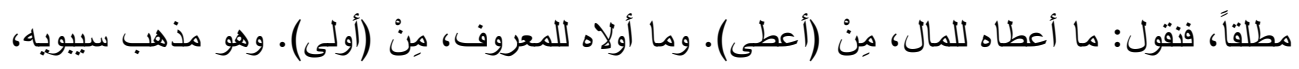

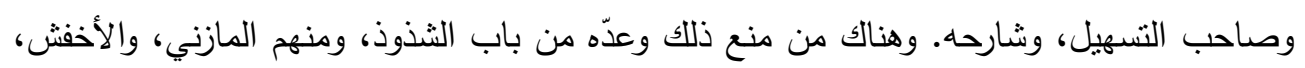

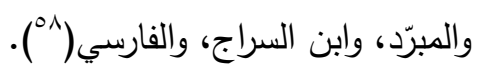

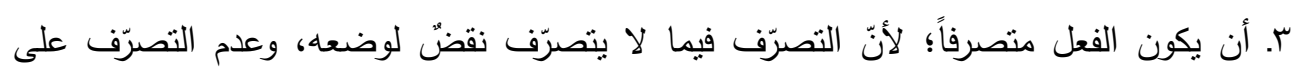
أ. يكون بخروج الفعل عن طريقة الأفعال من الدلالة على الحدث والزمان، نحو: (نِعْمَ، وبُِِسَ). فلا

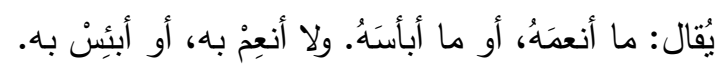

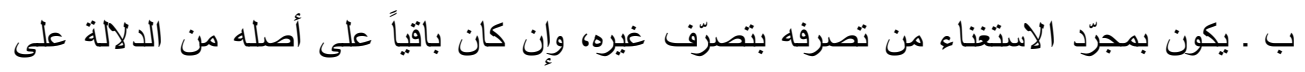

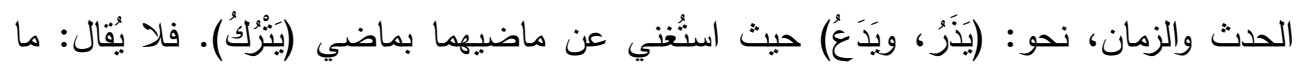

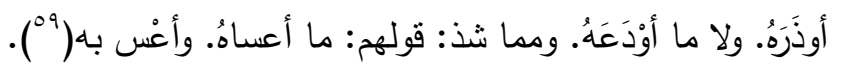

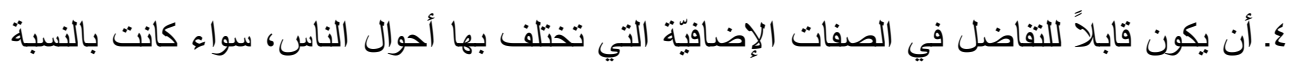

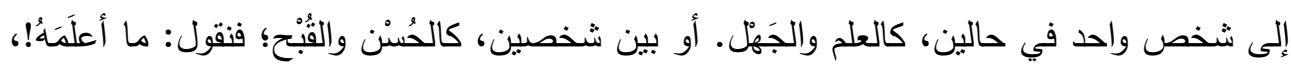
وما أجهلَهُ!. بخلاف ما لا يقبل التفاضل ويشترك فيه الجميع، فلا يُنينيان من نحو : (فَبْيَ، ومَاتَ)؛؛

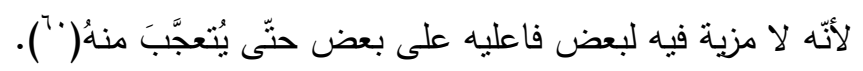

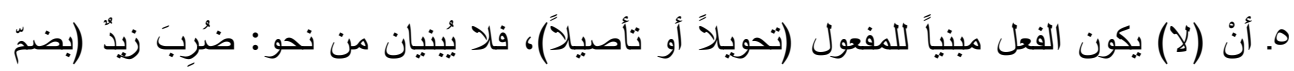

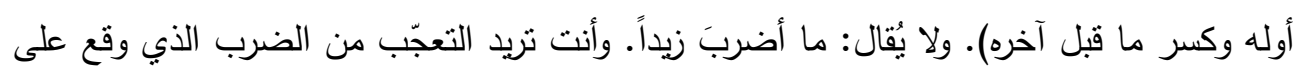

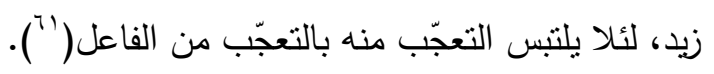

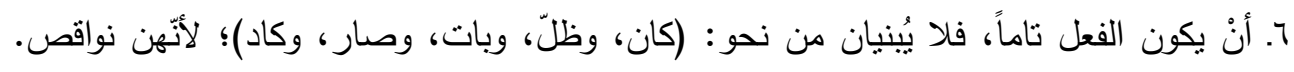

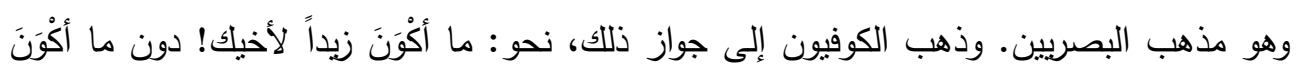

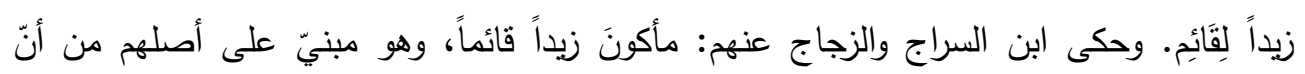

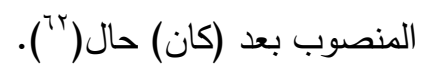
V. أن يكون الفعل مثبتاً، فلا يُنينان من فعل منفي، سواء أكان ملازماً للنفي، نحو : ما عَاجَبالدواء،

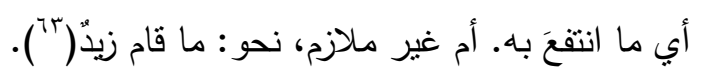

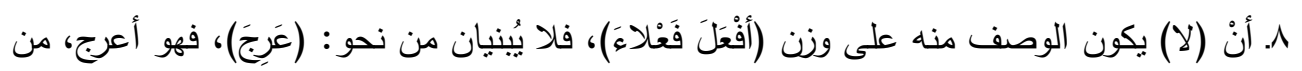

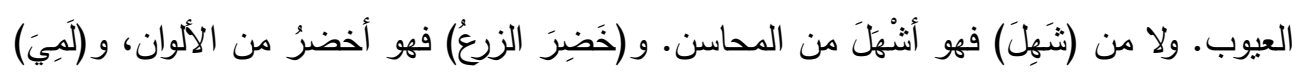

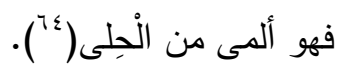
وذكر سييويه سبياً تاسعاً، وهو أن لا يُشتغنى عنه بالمصوغ من غيره، نحو : فال من القائلة،

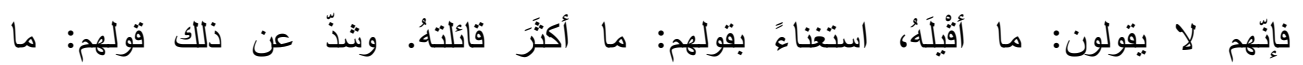




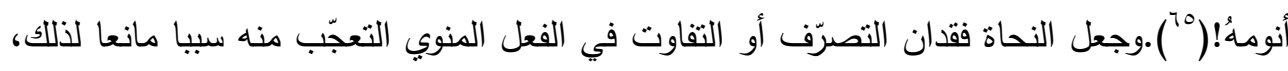

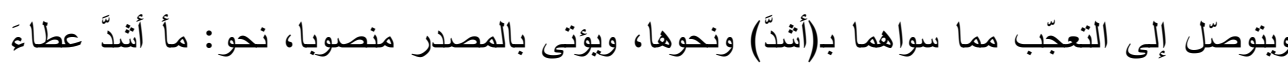

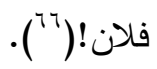
ثالثاً: إعراب صيغ التعجب

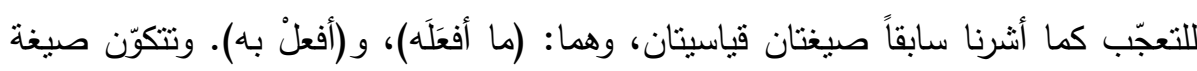

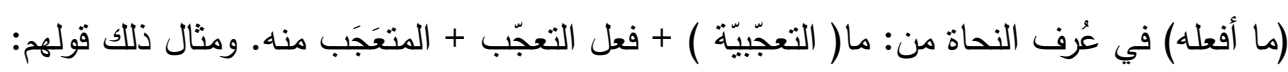

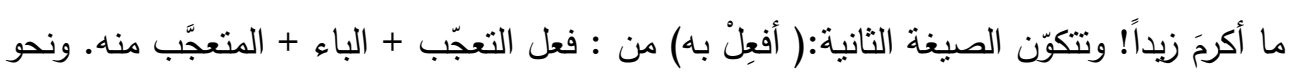
ذلك: أكرم بزيدٍ. والناظرفي هذا التركيب اللغوي يلحظ أنّه واضح لا يحتاج إلى الكثير من العناء في المعرفة

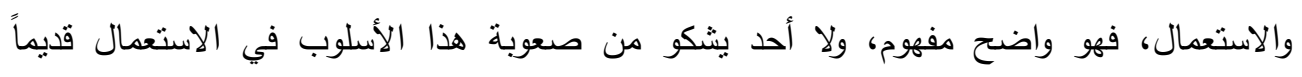

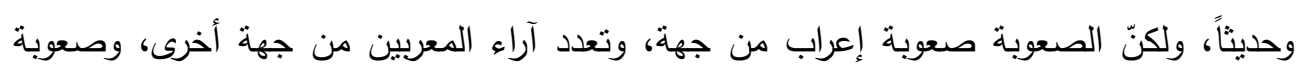

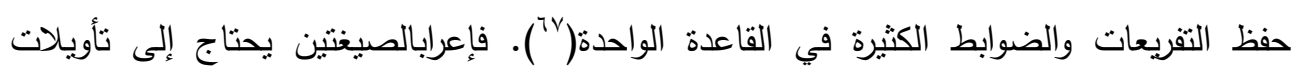
وتقديرات قد لا يقبلها العقل أحياناً.

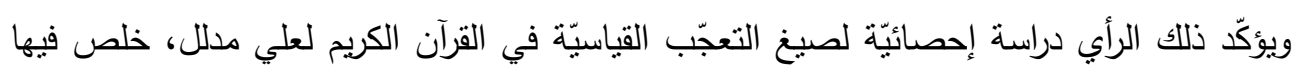

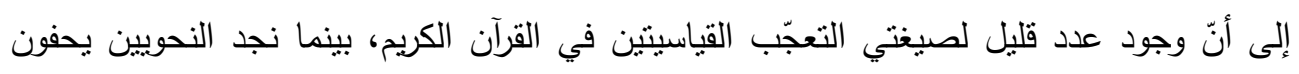

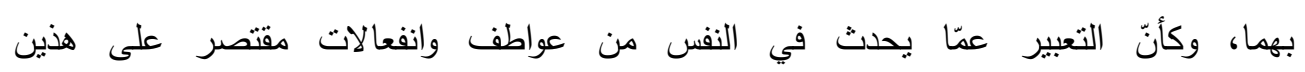

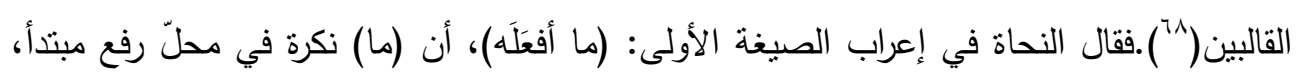

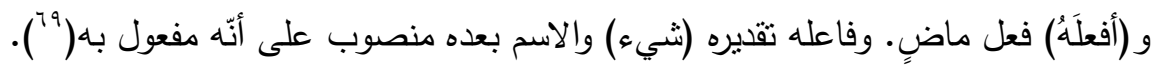

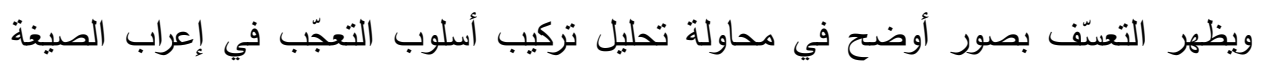

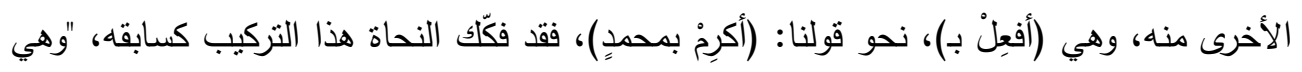

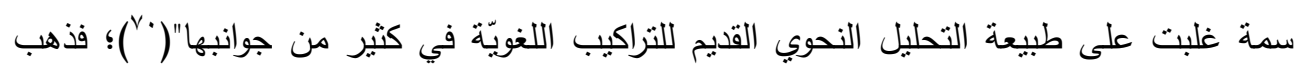

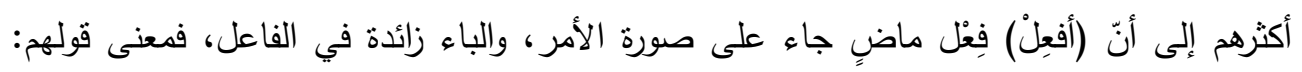

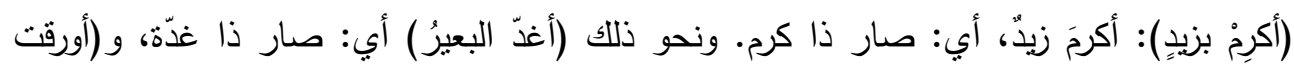

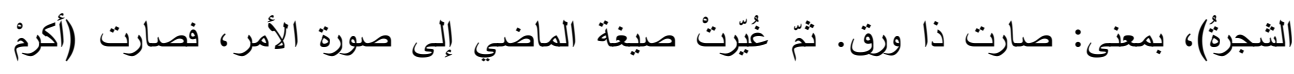

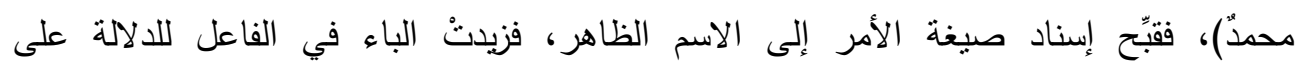

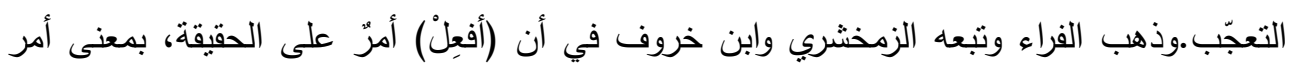

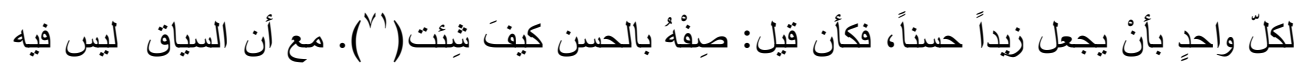

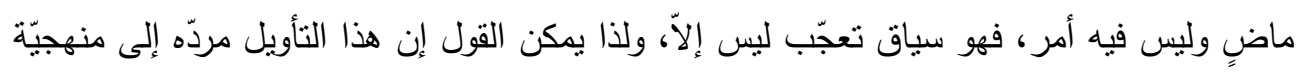

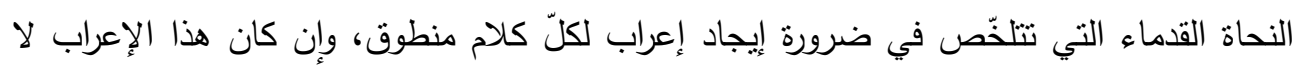

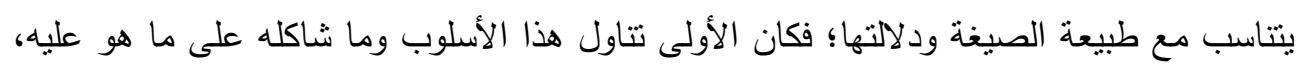


وإذا كان لا بدّ من إعرابه نقول: أسلوب جامد لإنشاء التعجّب معبّراً عن حالة نفسيّة، أو الاكتفاء

$$
\text { بإعراب واحد (فعل أمر). }
$$

رابعاً:إعراب الاسم المتعجّب منه

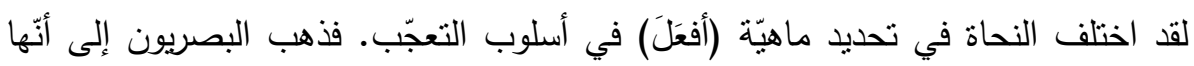

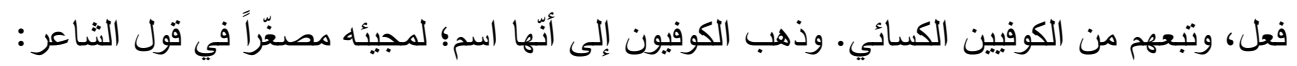

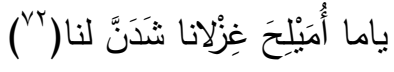

وأخذ برأي الكوفيين بعض الباحثين المحثثن، منهم جميل علوشفي حديثه عن طبيعة

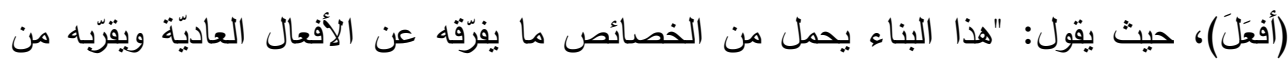

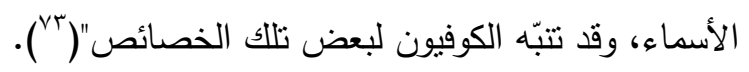

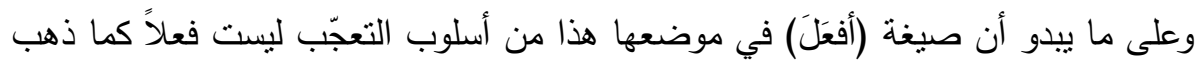

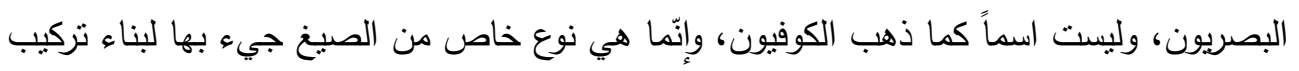

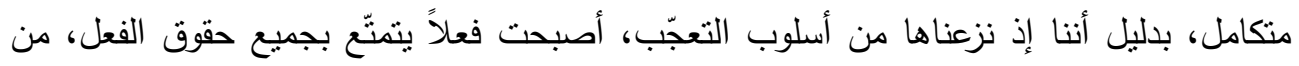

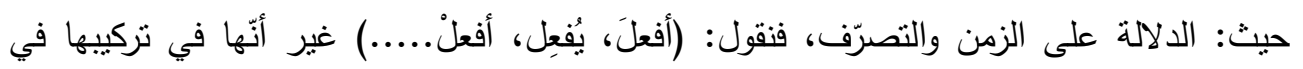

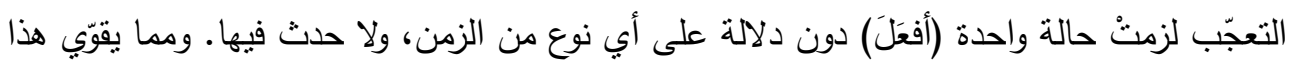

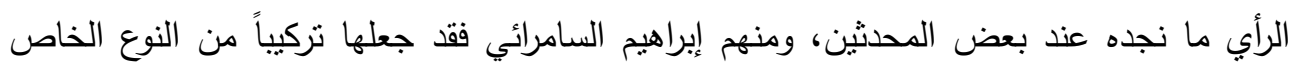

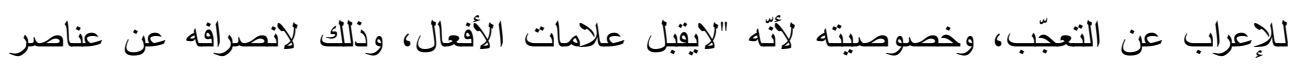

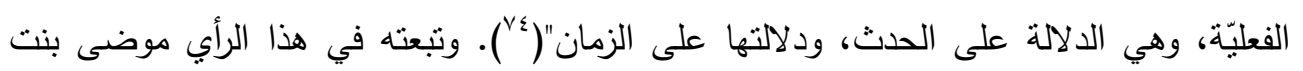

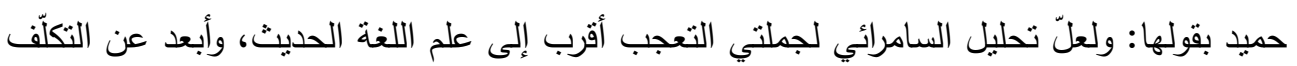

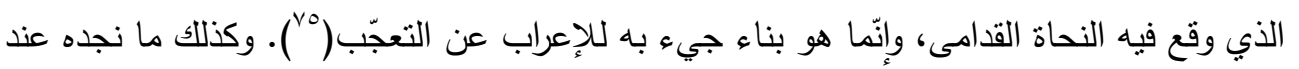

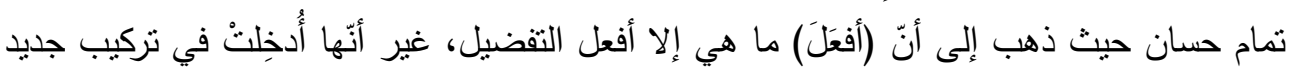

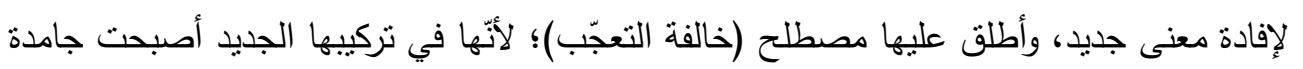
لا تقبل الإسناد أو التصرّف (1/7).

وقد كان لاختلاف النحاة - سابق الذكر - في تحديد ماهيّة (أفعَلَ) بين الاسميّة والفعليّة

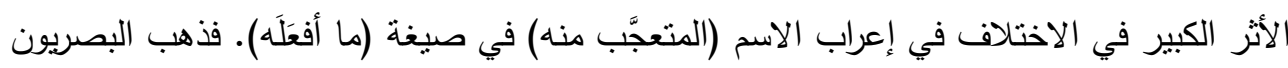

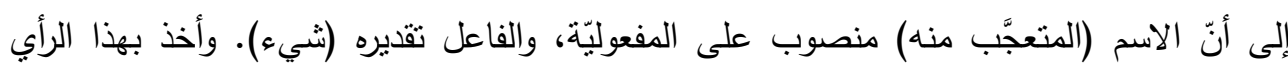

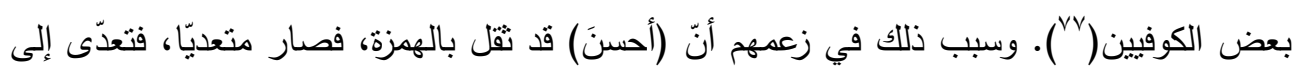

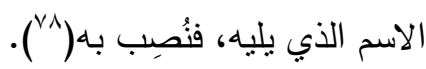
أما الكوفيون فيرون أنّ الاسم انتصب على فلى أنّه صفة للمتعجّب منه، فأشبه (المتعجّب منه)

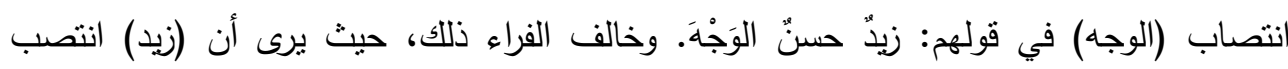


ب(أفعلَ)، من قبيل التفريق بين الاستقهام والخبر ، فالأصل (زيدّ أحسنُ من غيره)، فأنوا بـ(ما)، فقالوا:

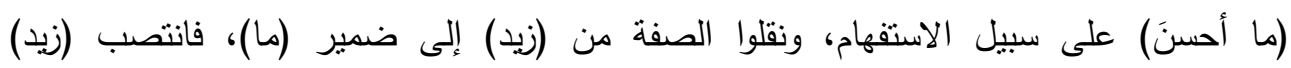

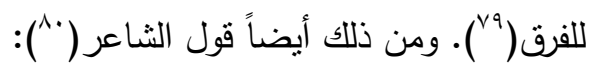

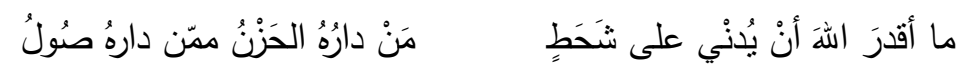

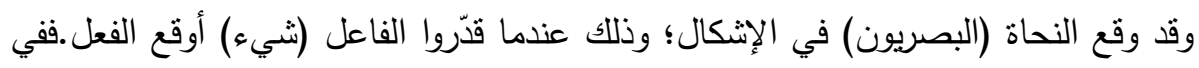

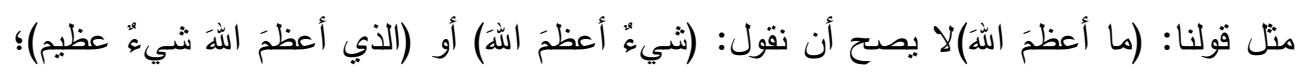

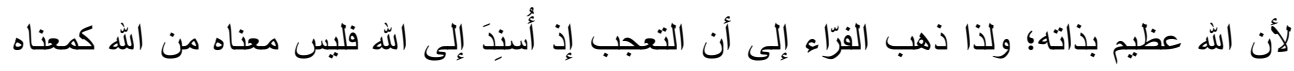

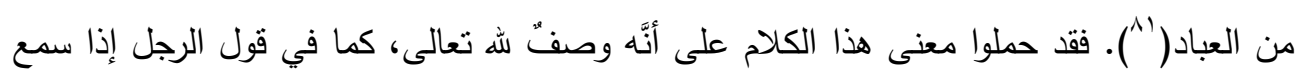

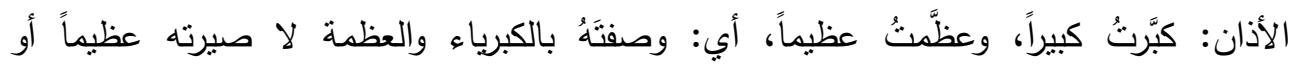

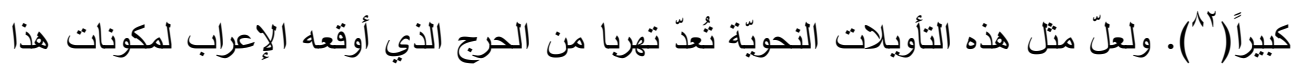

$$
\text { التزكيب اللغوي. }
$$

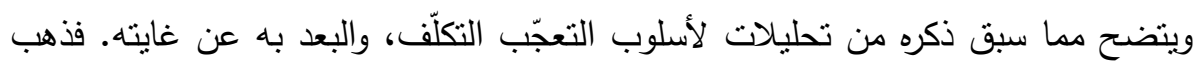

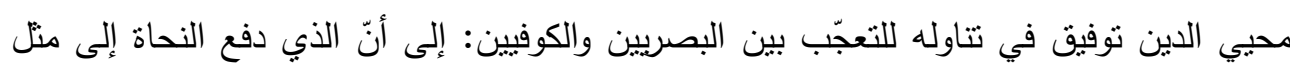

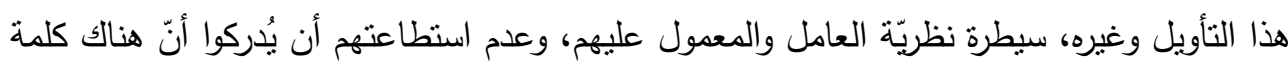

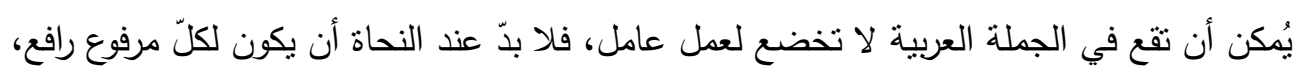

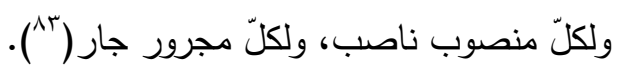

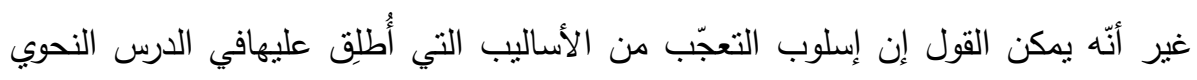

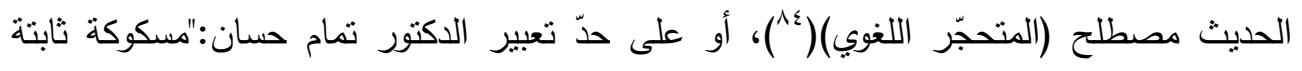

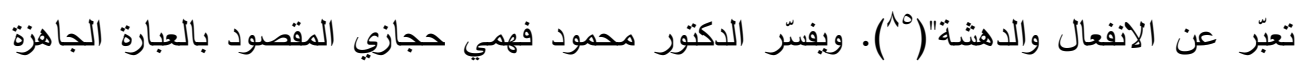

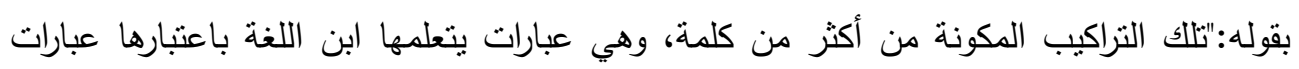

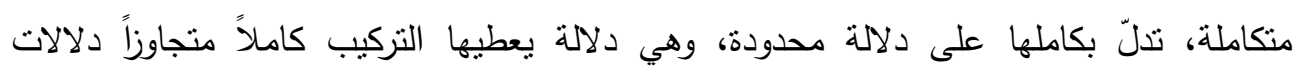

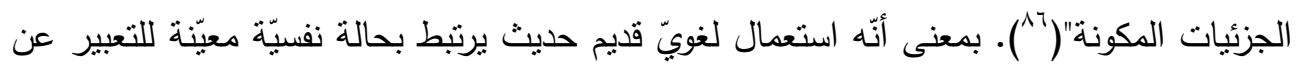

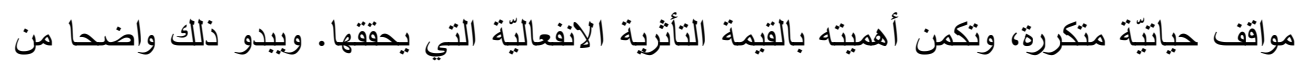

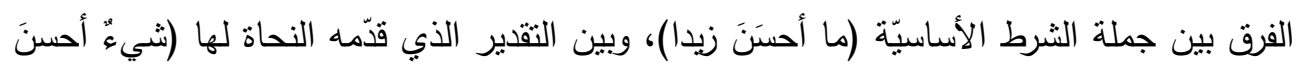

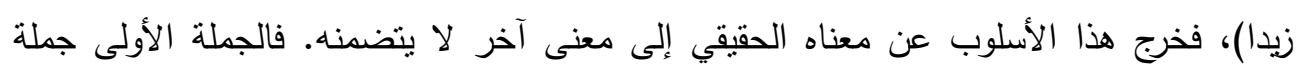

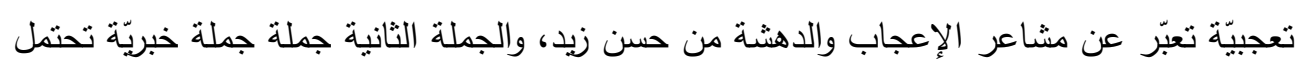

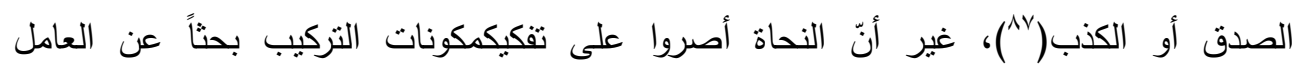

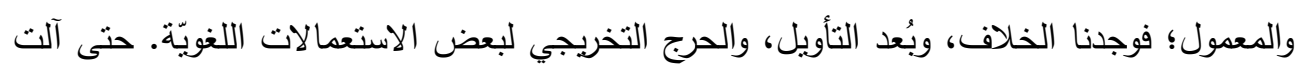

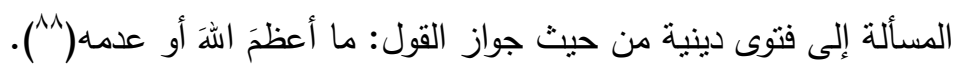




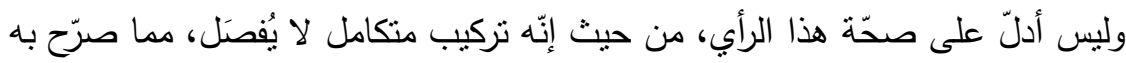

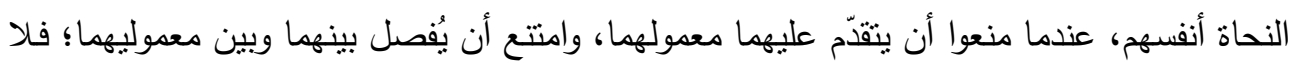
تقول: (ما زيداً أحسنَ) بتقديم معمول (أحسن) عليه، ولا تقول: (بزيدٍ أحسن) بتقديم معمول (أحسن)

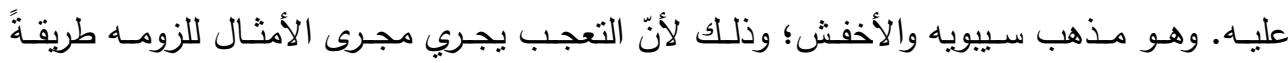

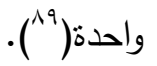

يمكن القول إن الحركة الإعرابية في أسلوب التعجّب وما شابها من التراكيب الثابتة في

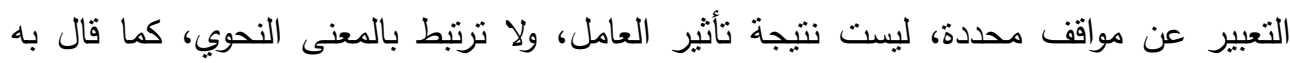

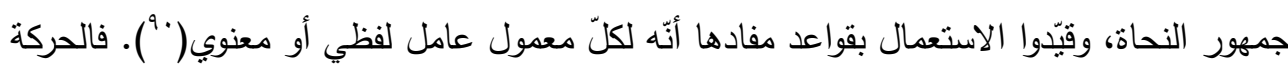

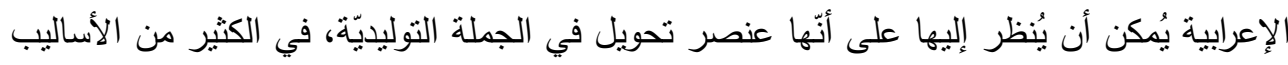

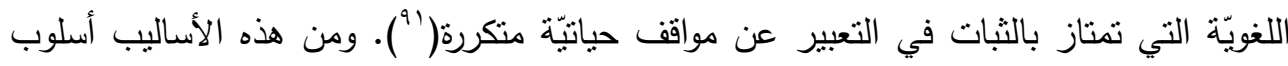

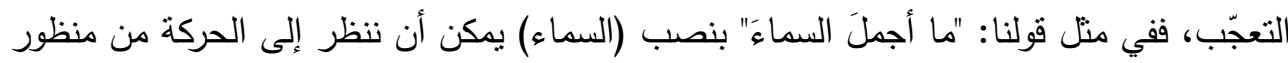
آخر مخالف لوجهة نظر النحاة القدماء، وهو أنّه قد جيء بالحركة لبيان الفرق بين نركيب وآخر بينهما توافق شكلي في البنية الخارجية، واختلاف في الدلالة، وتوضيح ذلك على النحو الآتي:

\begin{tabular}{|c|c|c|}
\hline المغنى & الجملة & $p$ \\
\hline التعجّب & ما أحسنَ زيداً! & 1 \\
\hline الاستقهام & ما أحسنُ زيدٍِ & r \\
\hline النفي & ما أحسنَ زيدُ & $r$ \\
\hline
\end{tabular}

وكذلك الحال بالنسبة للناصب في الأساليب مطرّدة الاستعمال: كالتحذير، والاختصاص، والإغراء، وغيرها، فقد قال النحاة بأن عامله محذوف، يقدرونه فعلا، غير أنّ الواقع على ما يبدو غير ذلك؛ فيكون تغيّر الحركة دلالة على تحوّل الجملة منالنمط الإخباري إلى نمط آخر من الجمل

\begin{tabular}{|c|c|c|c|c|}
\hline \multicolumn{5}{|c|}{ سمي ب(الإفصاحية)(( "9)،موضحة على النحو الآتي: } \\
\hline المعنى & الجملة & المعنى & الجملة & b \\
\hline (الاختصاص) & نحنُ العربَ & (الإخبار ) & نحنُ العربُ & 1 \\
\hline (التحذير ) & الأسدَ & (الإخبار ) & الأسدُ & $r$ \\
\hline (الإغراء) & الصدقَ & (الإخبار ) & الصدقُ & r \\
\hline
\end{tabular}

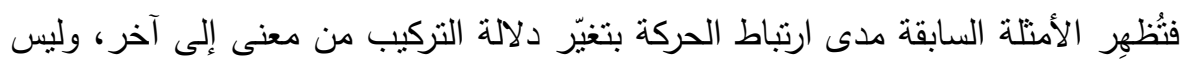

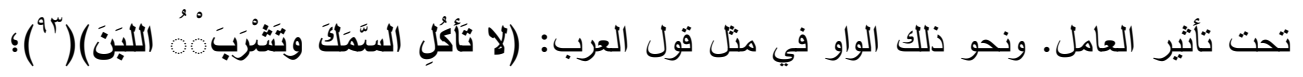
فتكون الحركة في نهاية الفعل (تترب) دلالة على تحوّل النمط الدالاي للتركيب اللغوي على النحو 
الأول: الفتحة، ويكون القصد النهي عن الجمع بينهما، بمعنى: يجوز للك أن تأكل السمك وحده أو تشرب اللبن وحده، لكن الممنوع هو الجمع بينهما.

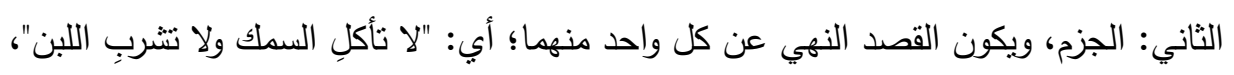

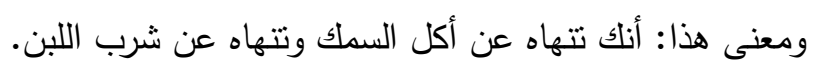

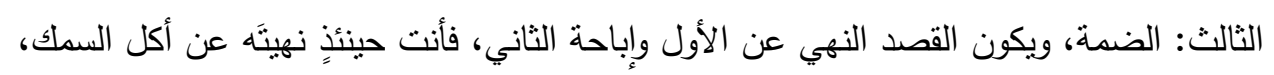

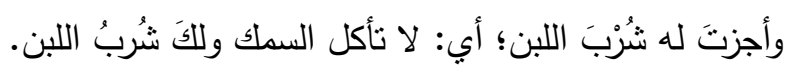

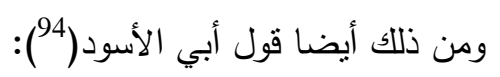

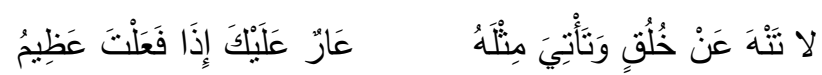

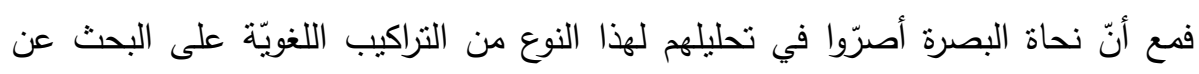

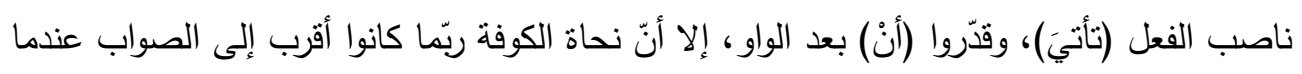

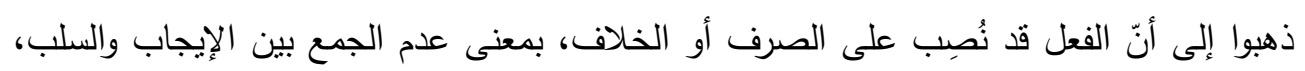

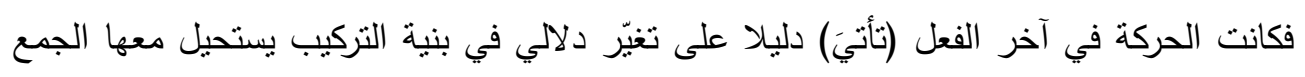

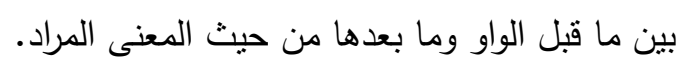

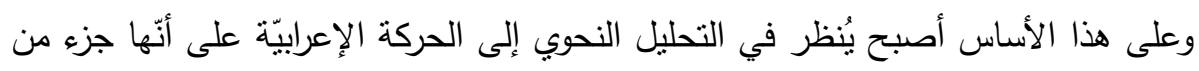

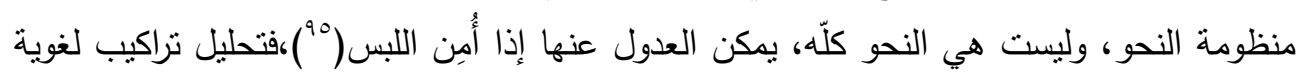

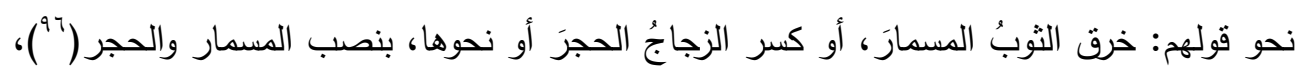

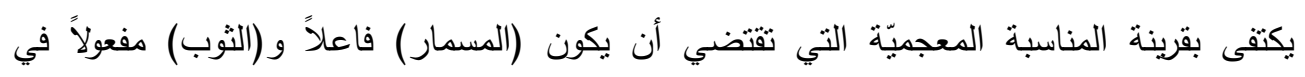
التركيب الأول. ويكون (الحجر ) فاعلاً و (الزجاج) مفعولاً في الثناني.

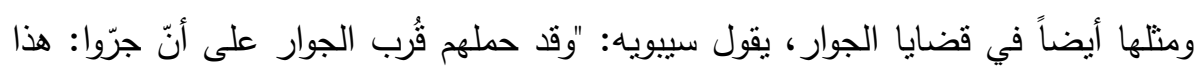

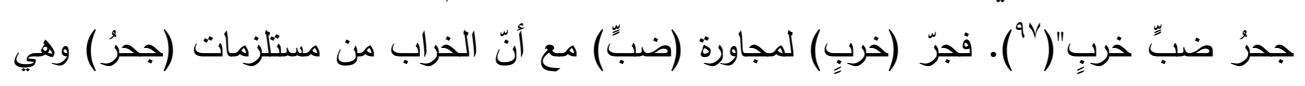

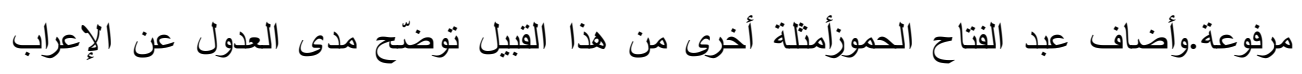

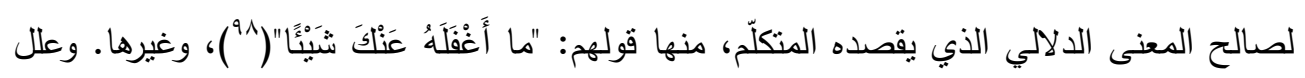

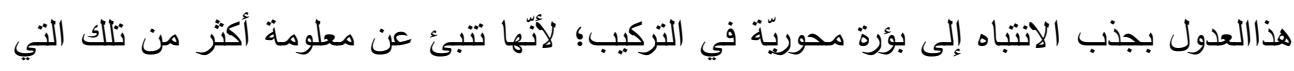

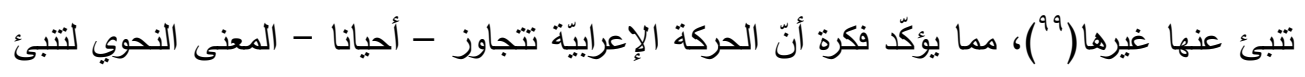
عن معنى دلالي يقصده المتكلّم.

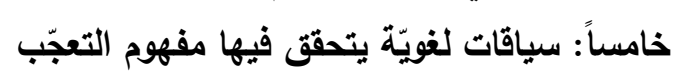

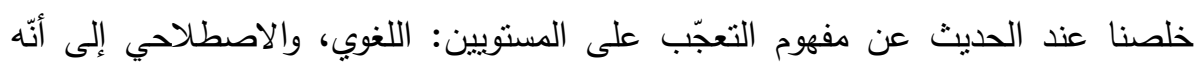

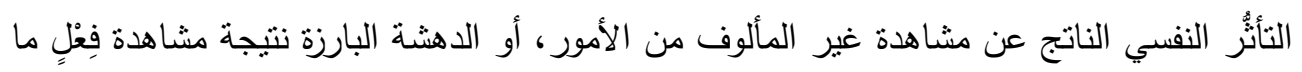

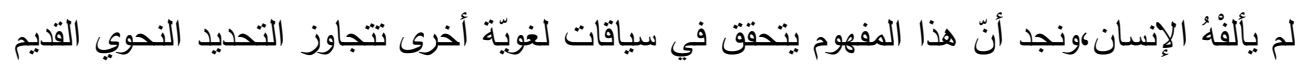

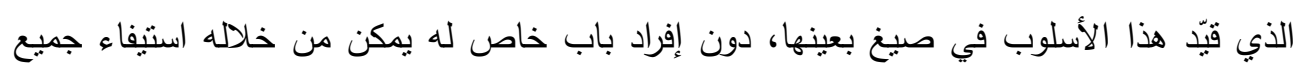


السياقات اللغويّة التي يمكن أن تؤدبّي الغرض الدلالي لهذا التركيب بصورة متكاملة، في حين وجدنا

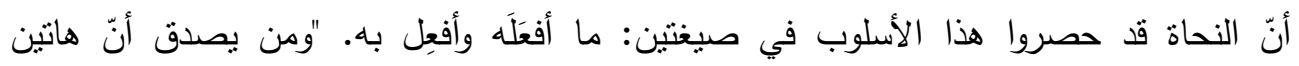

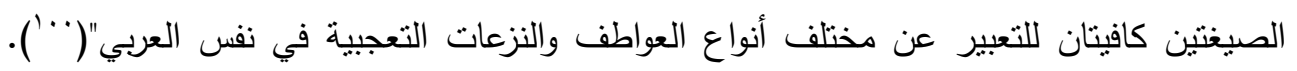

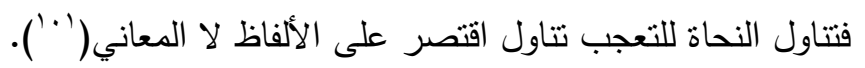

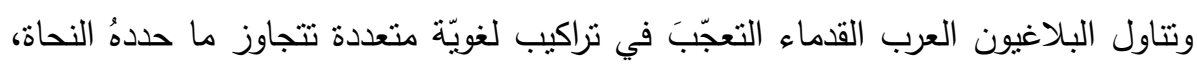

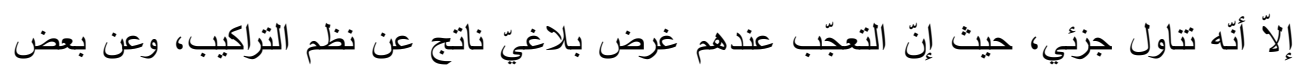

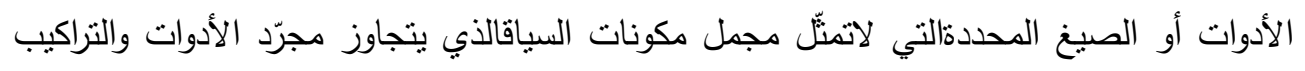

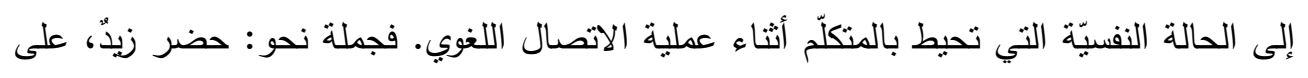
سبيل المثال، تتعدد دلالتها بناء على طبيعة الموقف الاتصالي بين طرفيه في سياق معيّن، وبناء

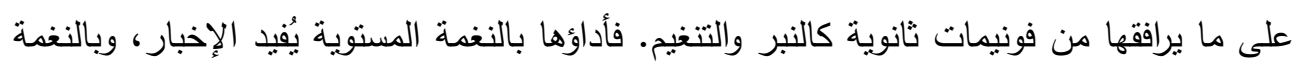

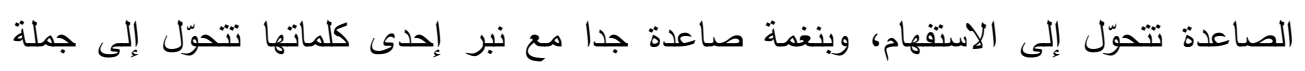

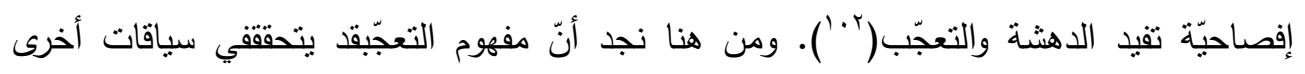

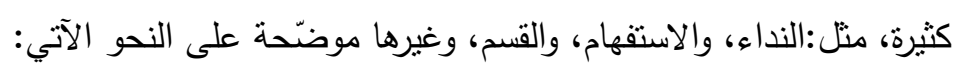

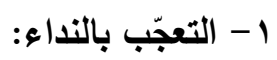

عرّف سيبويه النداء بقوله: كلّ اسم نُصِبَ على إضمار الفعل المنروك إظهاره، وتقديره

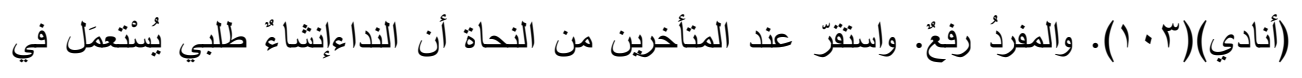

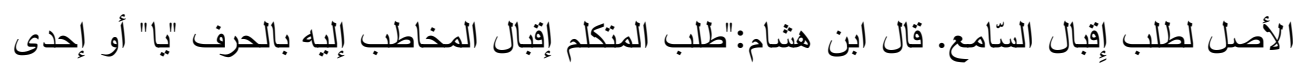

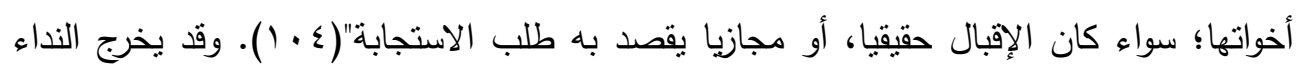

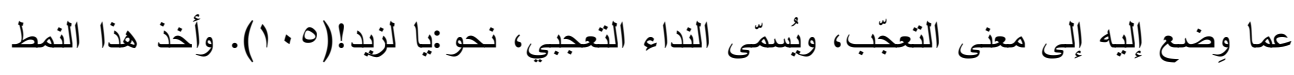
اللغوي دلالته الانفعالية من سياق التعجب الذي ورد فيه؛ "فأصبح من التراكيب المسكوكة في التعبير

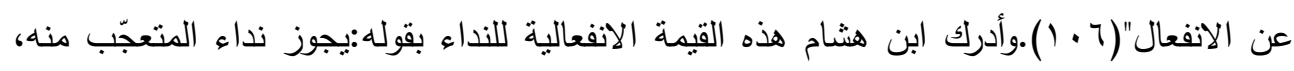

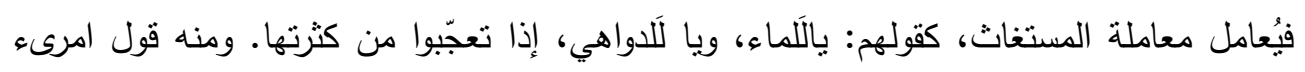
القيس(V) ( ) (1)

ويَوَمَ عَقَرتُ للعذارى مطيّتي فيا عجباً من كُورِها المُتحمَّلِ

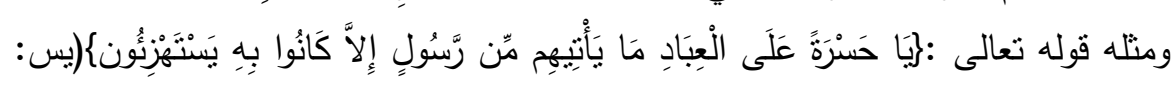

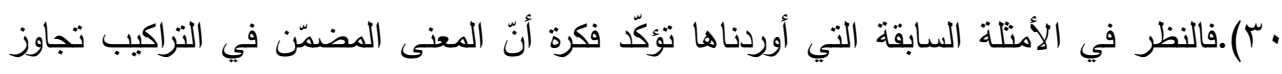

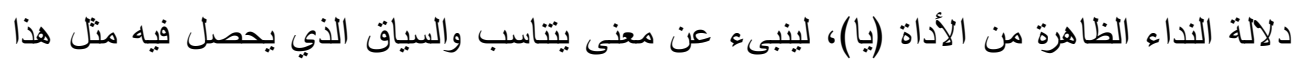

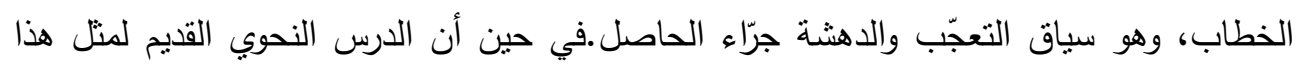

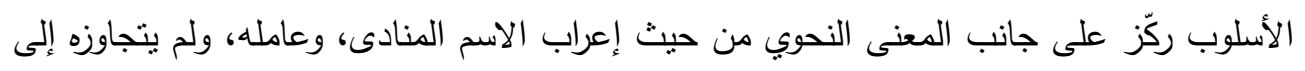

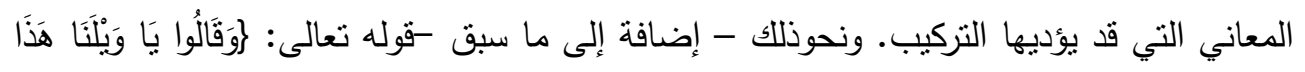




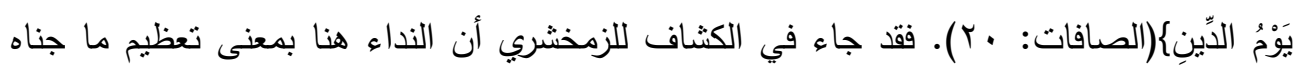

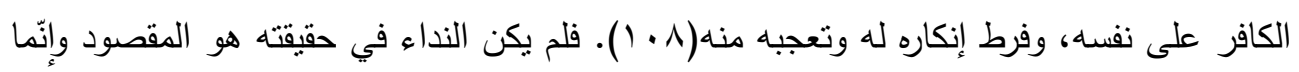
التعجّب والدهشة.

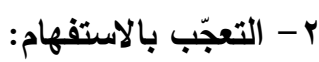

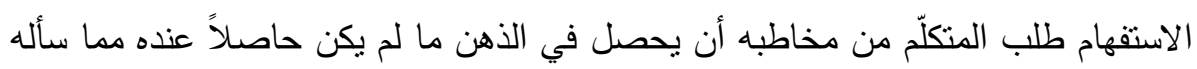

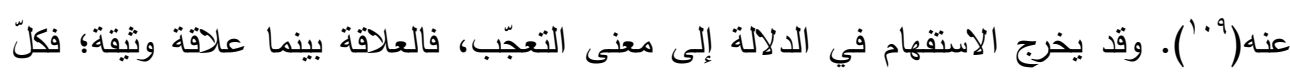

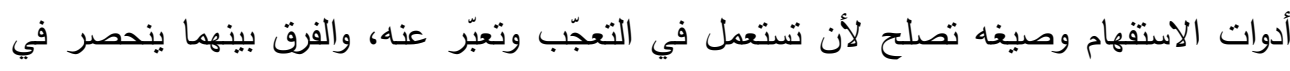

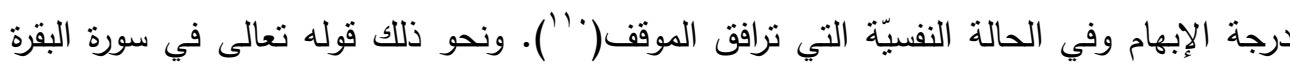

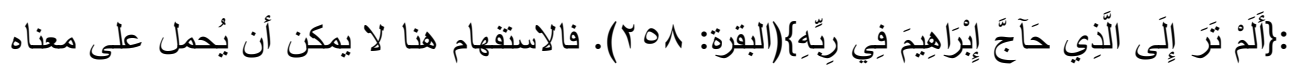

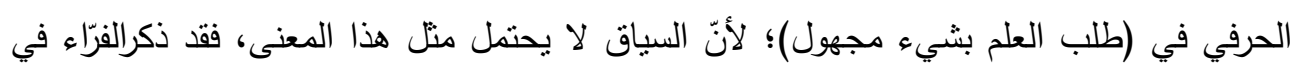

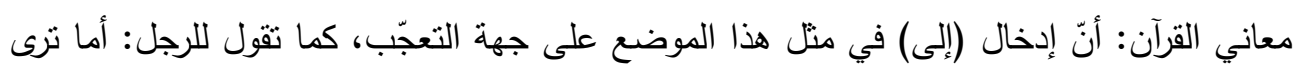

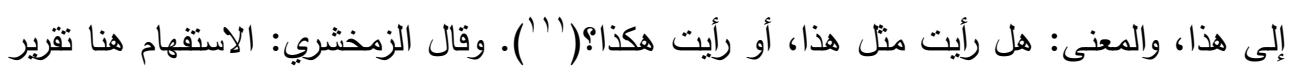

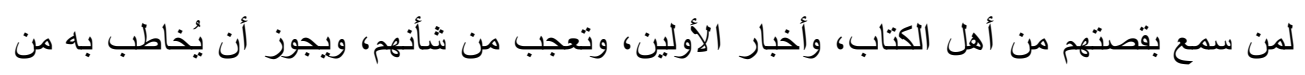

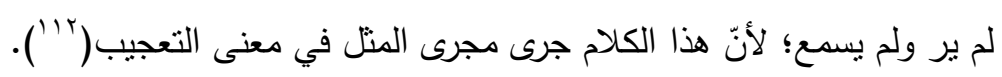

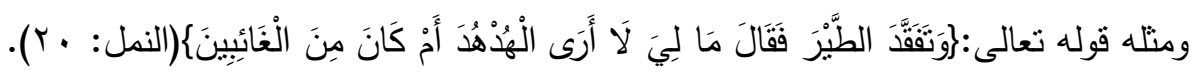

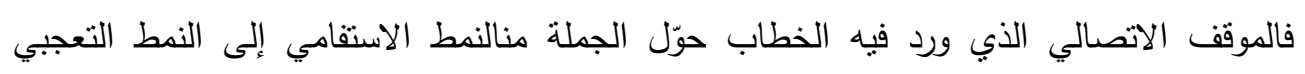

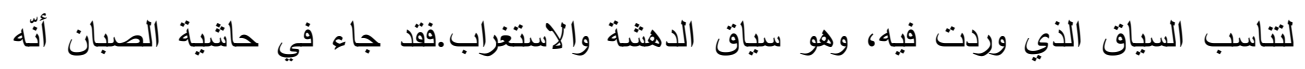

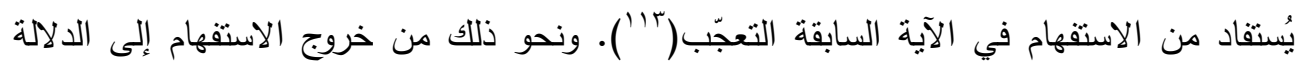

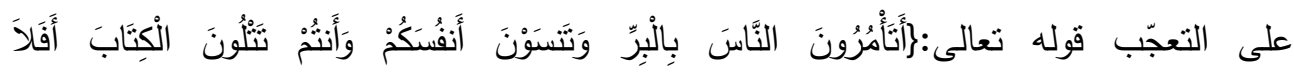

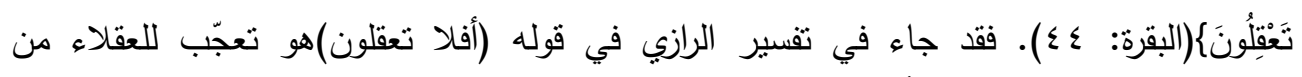

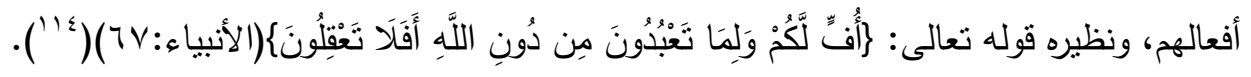

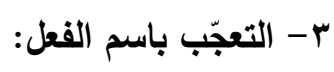

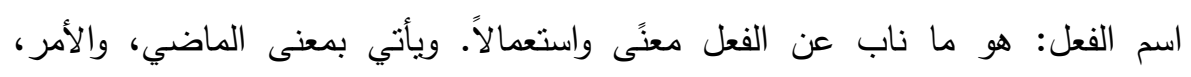

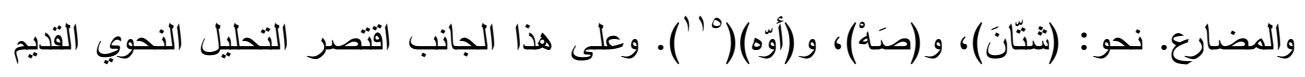

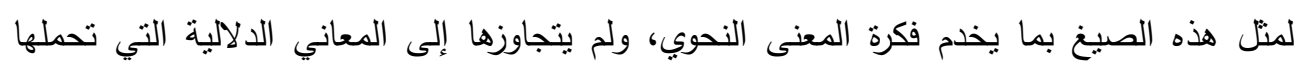

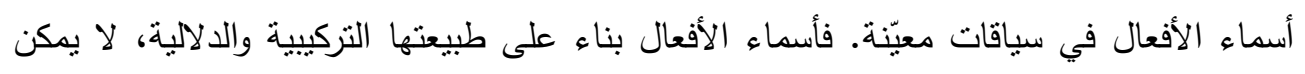

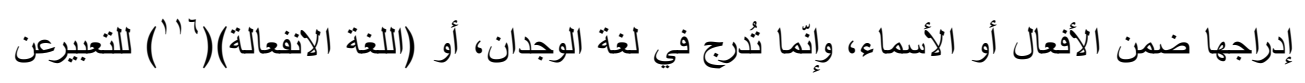

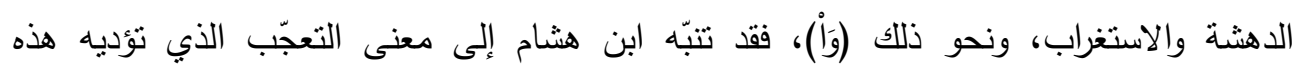

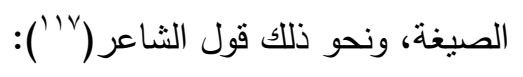

وا بأبي أنتِ وفوكِ الأَشْنَبَ 
كأنّما ذُرَّ عليه الزَّزنَبُ

ومن أسماء الأفعال التي تدّل على التعجّب (وَيْ)، قال الزمخشري: "ومن الأصوات قول

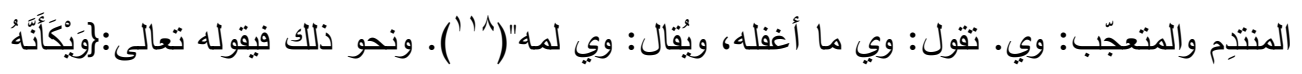

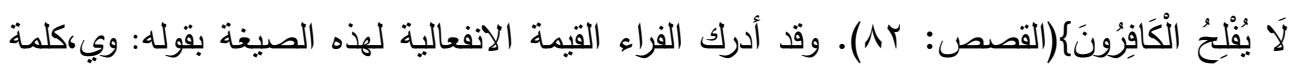

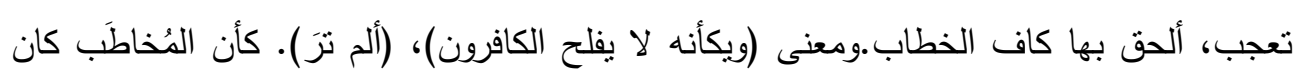

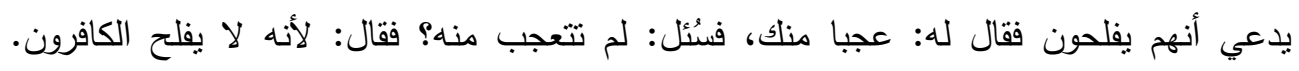

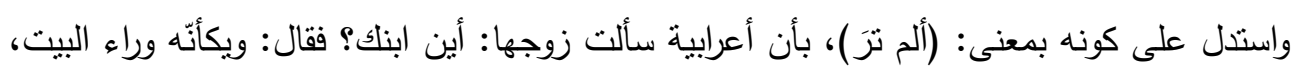

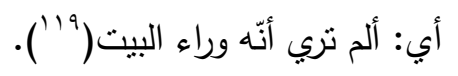

ومن هذا النوع صيغة (بخ)، "وهي كلمة تقال عند الأعجاب والرضى بالثئي، وتكرر

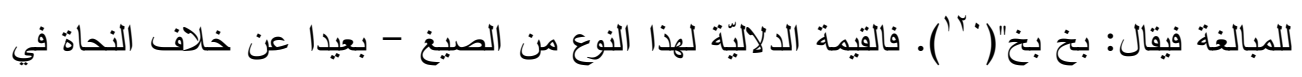

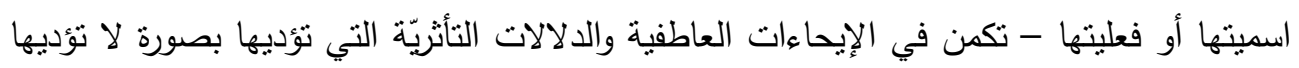
لفظة أخرى مكانها.

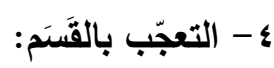

القسم: أسلوب من أساليب نوكيد الكلام، وإبراز معانيه، ويؤتى به في الغالب لافع إنكار

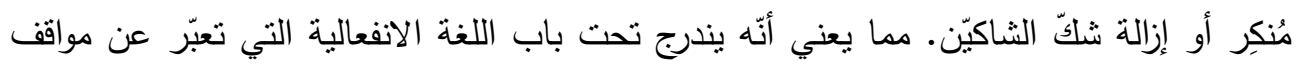

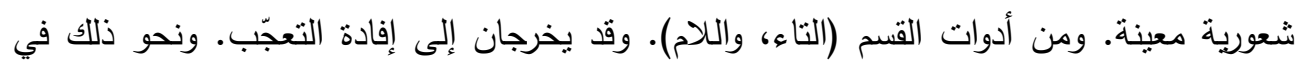

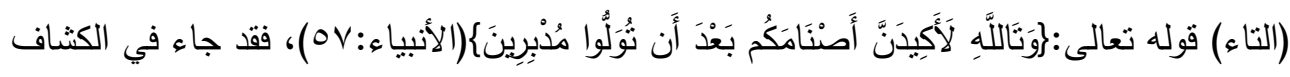

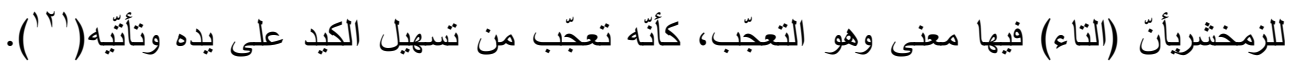

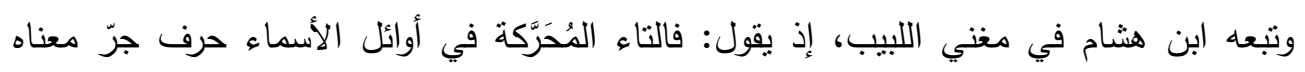

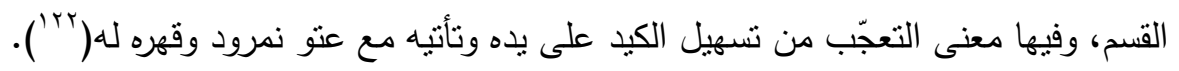

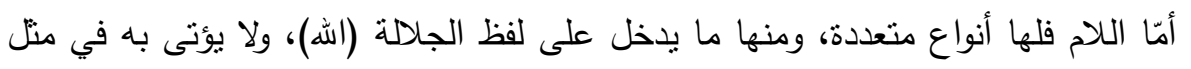

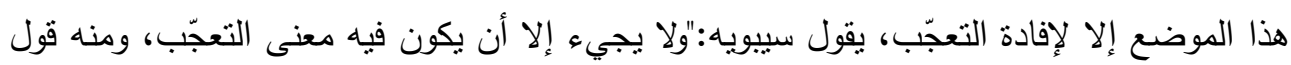

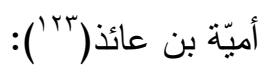

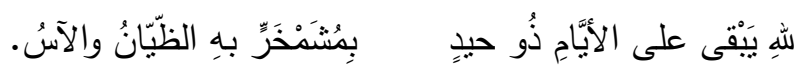

وجاء في شرح الرضي أن اللام تأتي بمعنى (الواو) في القسم للتعجّب، نحو (لله لا يؤخّر

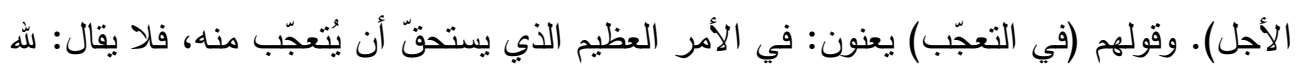

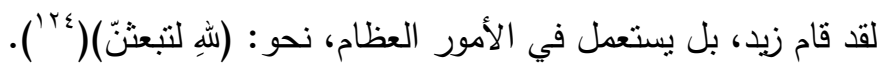


ه- التعجب بصيغة (كفى) وما في معناها:

لقد قام التحليل النحوي القديم في تتاوله لصيغة (كفى) وما في معناه، نحو : (كفى بالثيب

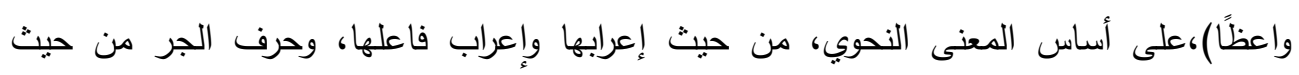

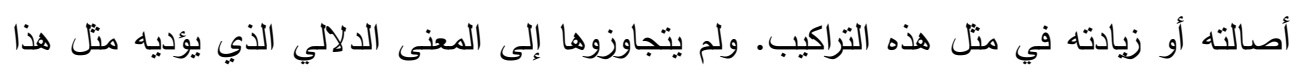

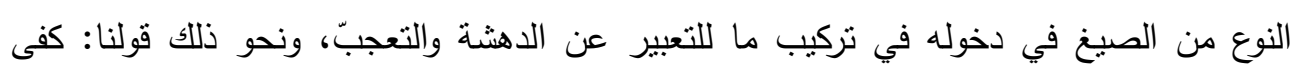

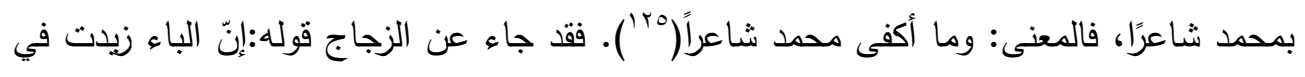

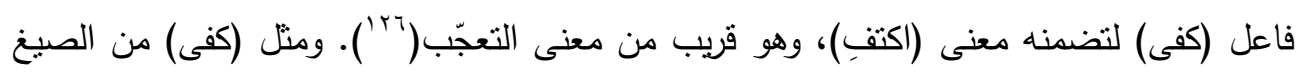

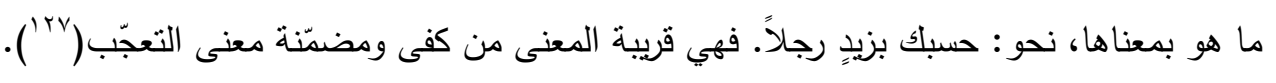

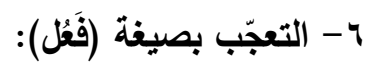

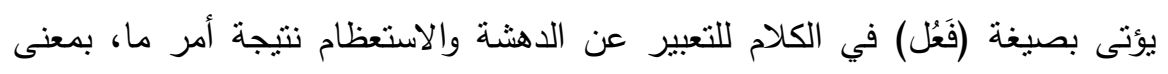

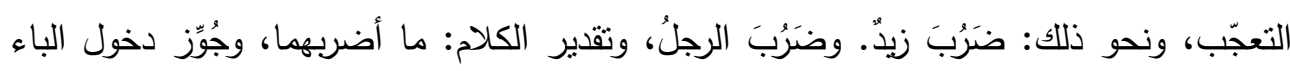

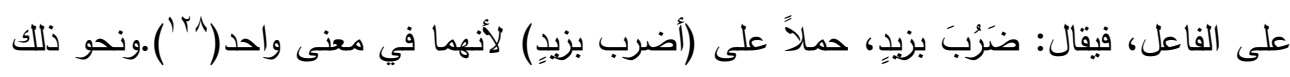

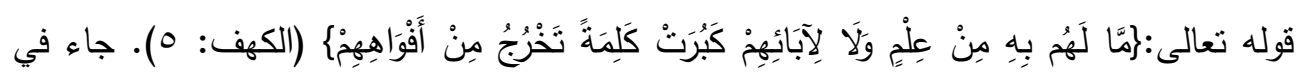
الكثاف للزمخشري أنّ (كلمةً) بالنصب على التمييز والرفع على الفاعليّة، والنصب أقوى وأبلغ، وفيه

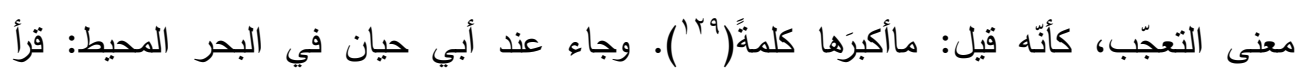
الجمهور (كلمةً) بالنصب، والظاهر انتصابه على التمبيز وفي ذلك معنى التهل التعجّب، أب ما أكبرها

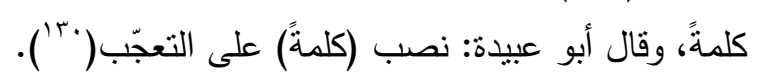

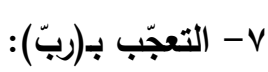

اختلف النحاة في (ربَّ)، فذهب الكوفيون إلى أنّه اسم، وذهب البصريون إلى أنّه حرف

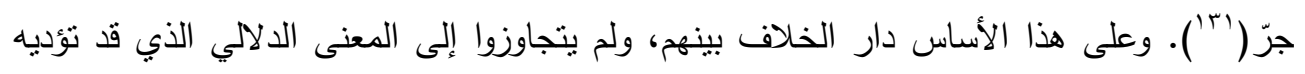

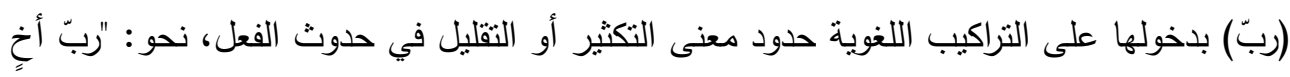

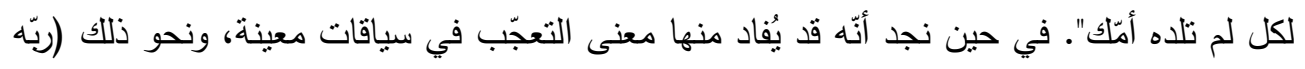

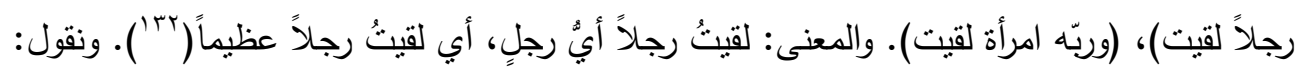

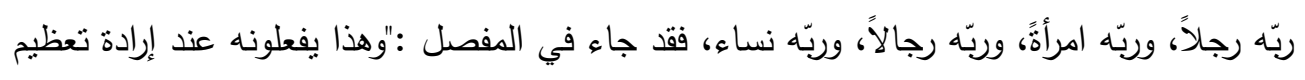

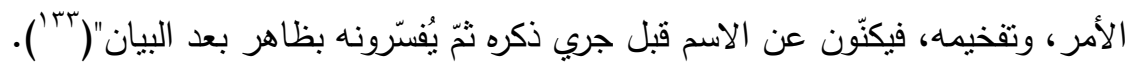
1- التعجّب بـ(أب) الكماليّة:

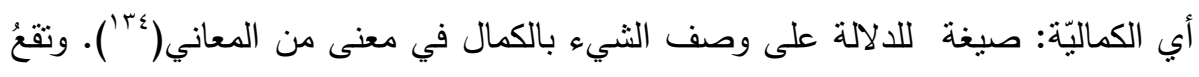

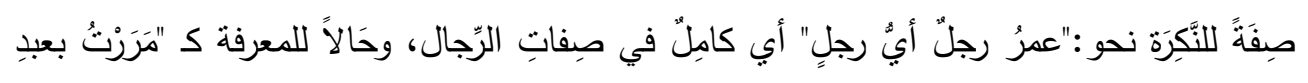

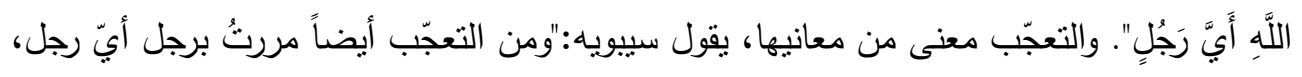

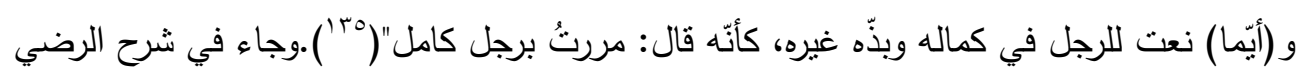


أنّ (أي) منقولة عن الاستفهاميّة، وذلك لأنّ الاستفهاميّة موضوعة للسؤال عن التعيين، وذلك لا

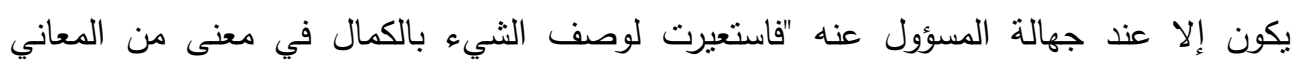

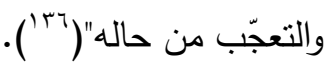
نتائج الدراسة:

بعد العرض السابق لمعايير النحاة في نتاول الأساليب اللغويّة وتحليلها بشكل عام، وأسلوب التعجّب بشكل خاص خلصت الدراسة إلى النتائج والتوصيات الآتية:

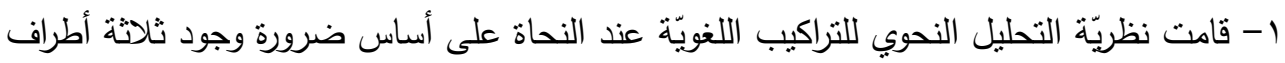
لا بد من توافرها: العامل، والمعمول، والحركة الإعرابية رمز ناثثر العامل بالمعمول.

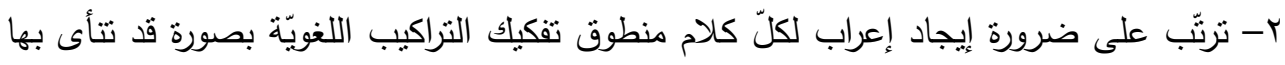
عن الدلالة التي وضعت لها، فيُصبح الإعراب شيئاً ودلالة الأسلوب شيئًاً آخر .

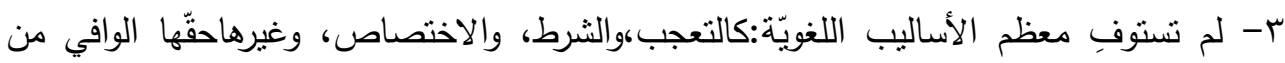
الدراسة الدلالية بسبب الاهتمام بالمعنى النحوي. ع- ليس من الضروري ارتباط الحركة الإعرابية في مجمل الأساليب اللغويّةبالعامل قدرارتباطها

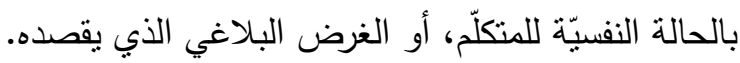
ه- أصبح يُنظر إلى الحركة الإعرابية في التحليل النحوي الحديث على أنّها جزء من منظومة النحو وليست هي النحو بأكمله، ويمكن العدول عنها في ظلّ توافر القرائن الأخرى. ז- يوصي الباحث من خلال هذه الدراسة بضرورةإفراد باب خاصّ في النحو العربي يتمّ فيه استيفاء أسلوب التعجّب من خلال جميع السياقات اللغويّة التي يتحقق فيها هذا المفهوم، متجاوزة التحديد الذي قيّده الدرس النحويالقديم بصيخ بعينها.

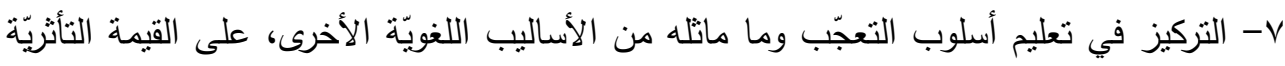

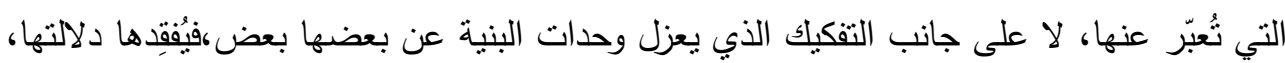
^- إذا كان لا بدّ من تقديم إعراب لتركيب التعجّب يمكن أن يُكتفى بالقول: أسلوب جامد لإنشاء التعجّب معبّراً عن حالة نفسيّة. ل الدان.

\section{Abstract \\ Exclamation method in Arabic A new vision \\ By Bassem Younis Al-Badairat}

This research aims to reveal a new vision in the study of the method of exclamation in the Arabic language, by reviewing the curriculum of ancient grammarians in the study of this method and the suitability of this analytical method with its significance, where the old grammar research of the method of exclamation and similar linguistic methods based on grammatical meaning The methodology of this methodology has lost much of the 
significance of this method, and its study focused primarily on two formulas in creating exclamation points in Arabic language without specifying a special section for exclamation through which all methods and linguistic structures that can be The concept of exclamation is integrated. The study took a description and analysis approach, and the following questions will be discussed:

1- What are the criteria for grammatical analysis of the Arabic sentence in ancient grammatical studies?

2- To what extent does the grammatical analysis of linguistic methods correspond to its significance?

3- What are the results of the nature of the grammar analysis of the structure structure?

4- To what extent can the study of linguistic methods benefit from the opinions of the linguists and fundamentalists, who are more concerned with the semantic output of the linguistic method than the editorial aspect?

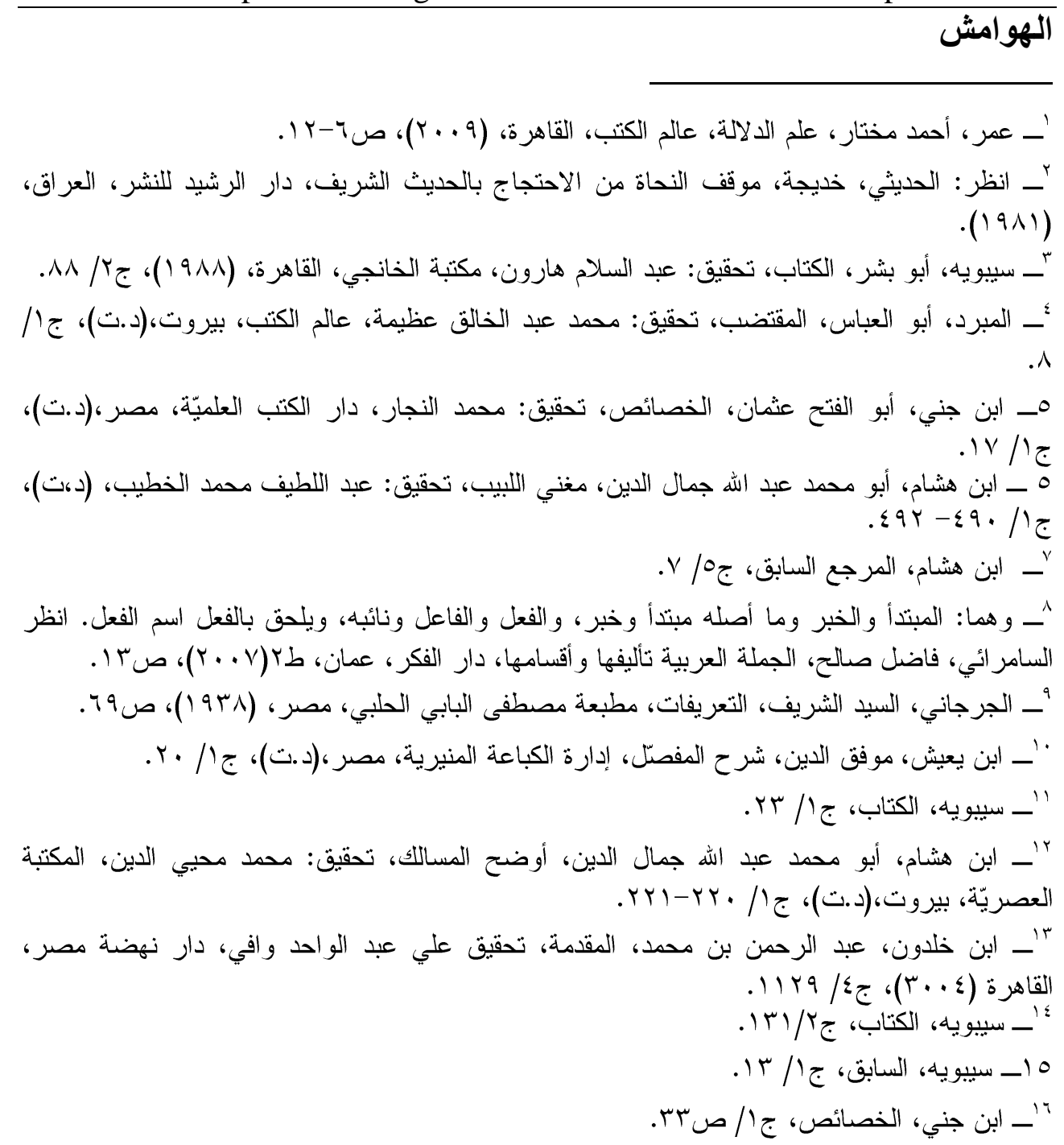




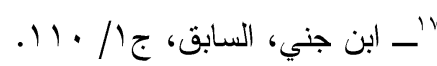

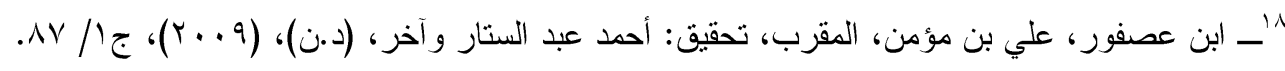
'ــ الصبان، أبو العرف محمد بن علي، حاشية الصبان، تحقيق: طه عبد الرؤوف سعد، المكتبة

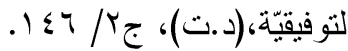

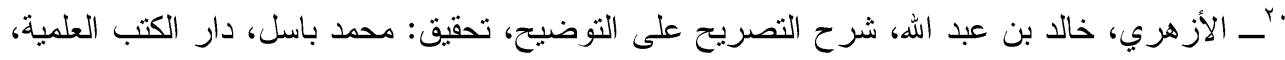

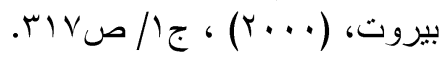

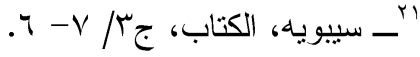

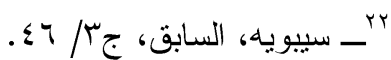

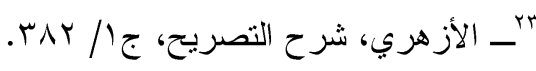

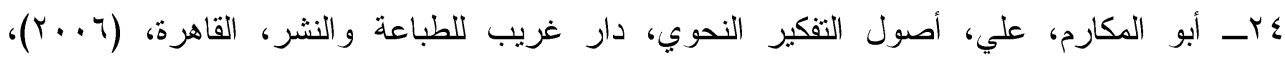

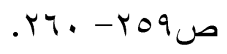

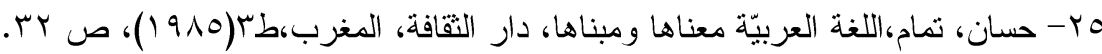
بr-_ الأنباري، عبد الرحمن بن محمد، نزهة الألباء في طبقات الأدباء، تحقيق: محمد أبو الفضل، دار

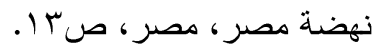

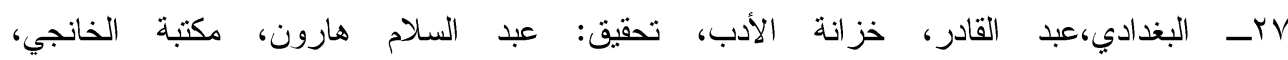

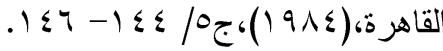

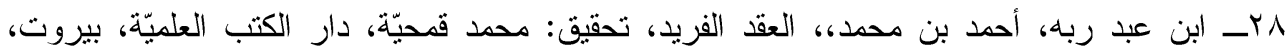

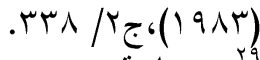

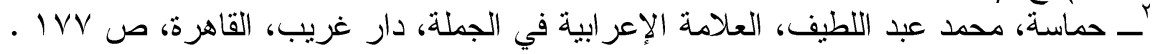

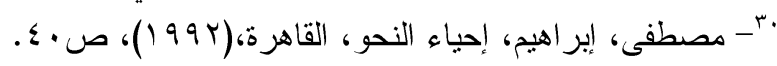

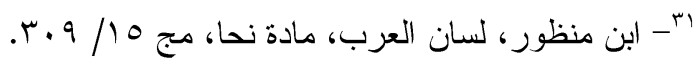
بr-_-السيوطي، جلال الدين، همع الهو امع، تحقيق: أحمد شمس الدين، دار الكتب العلمية، بيزوت، (د.ت)

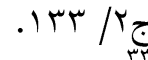

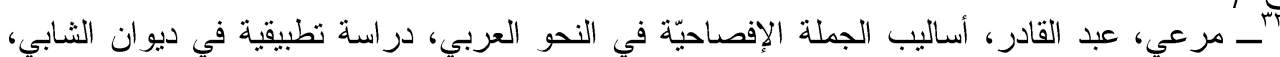

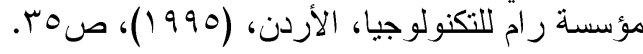

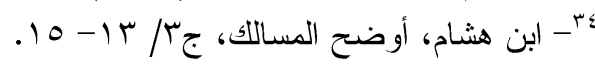

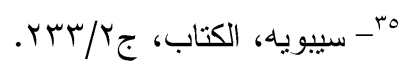

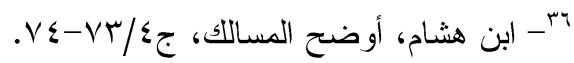

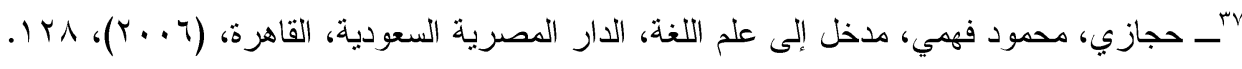

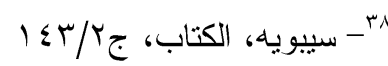

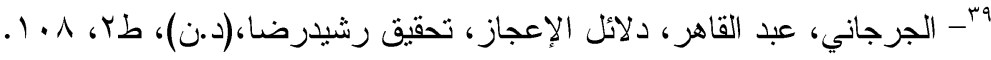

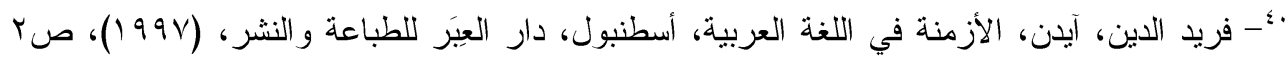
وما بعدها.

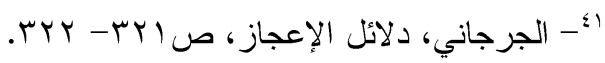

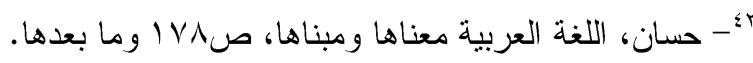


بأ- الأستراباذي، رضي الدين، شرح الرضي على الكافية، تعليق: يوسف حسن، منشورات جامعة

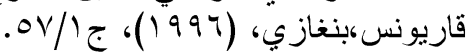
צ؛ آب ابن خلكان، أبو العباس شمس الدين، وفيات الأعيان، تحقيق: إحسان عباس، دار صادر، بيروت، مج .orv /

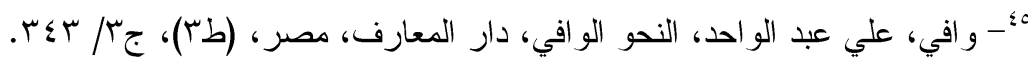

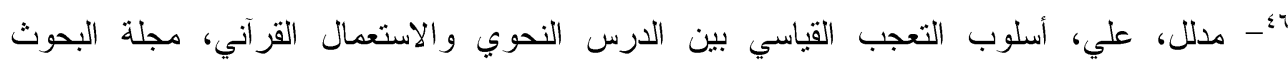

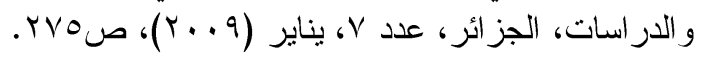

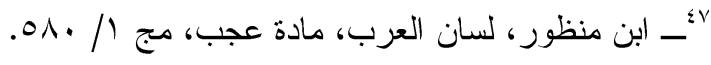

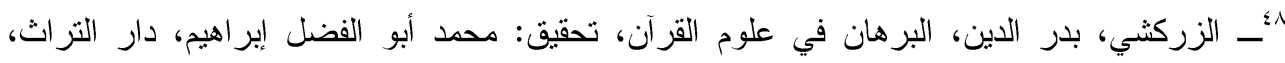

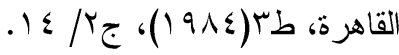

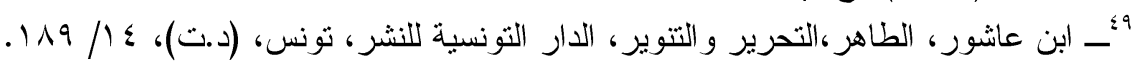

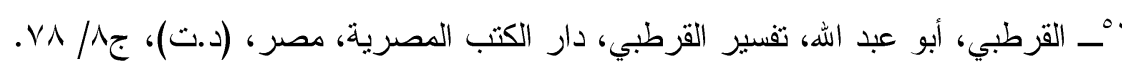

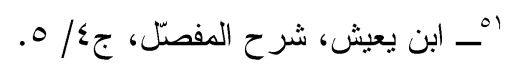

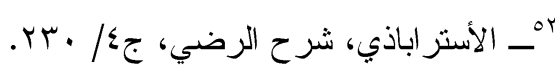

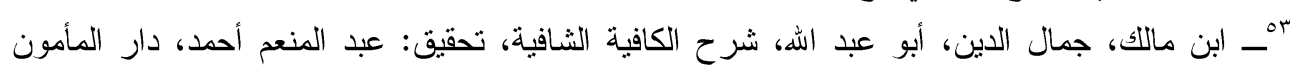

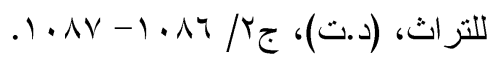

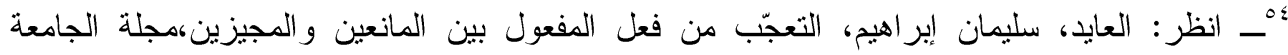

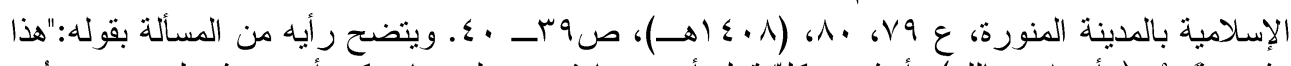

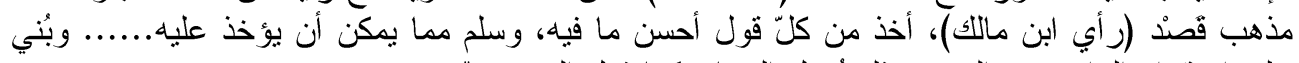

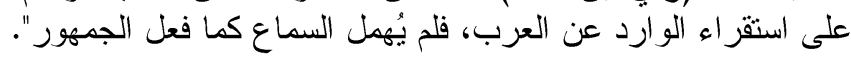

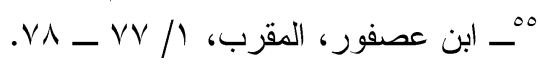

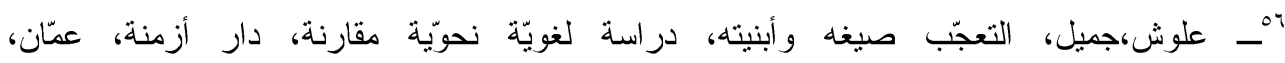

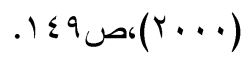

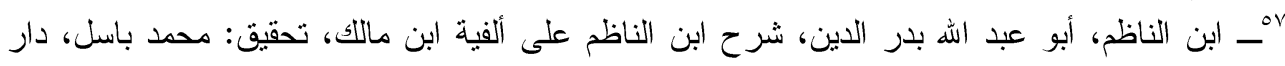

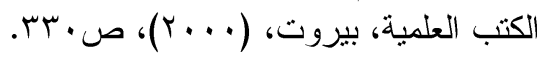

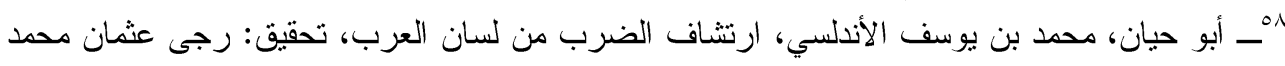

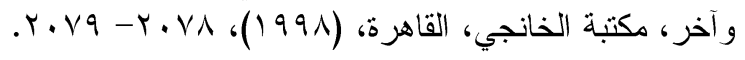

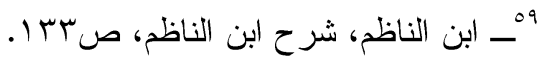

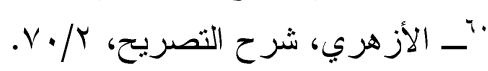

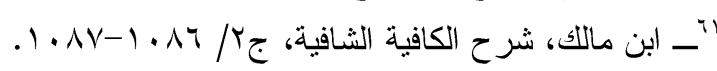

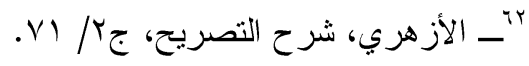

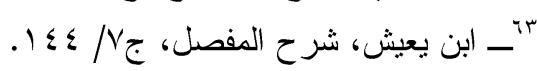

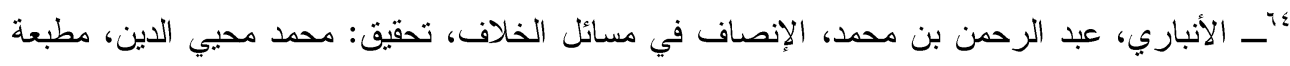

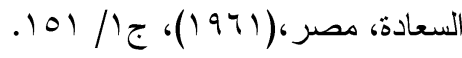
" 10

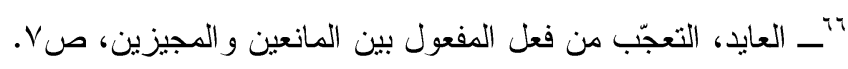


"ا_ نبهان، عبد الإله، "مقترحات في تيسير بعض صيغ الإعراب"، ورقة مقدّمة إلى مؤتمر تبسير تعليم

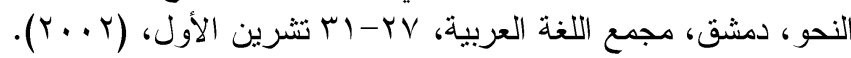

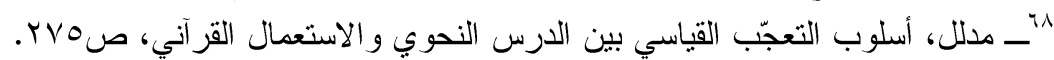

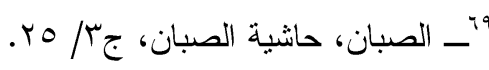

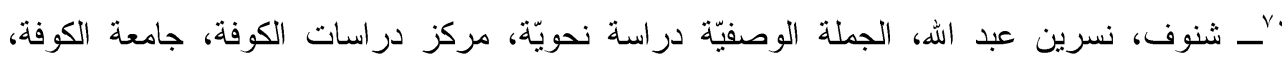

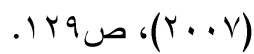

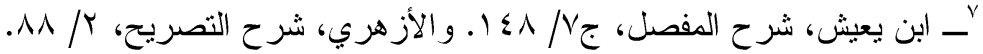
rr

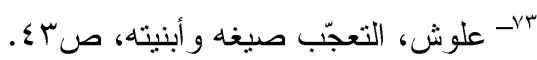

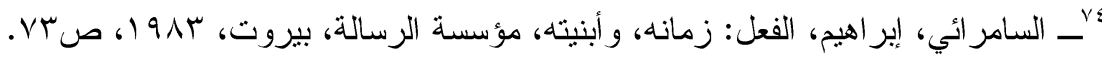

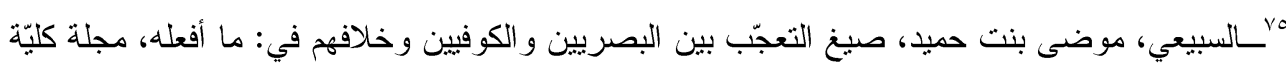

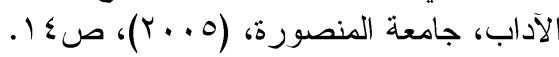

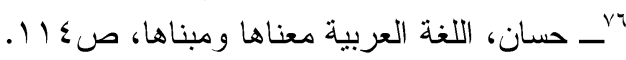

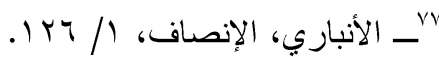

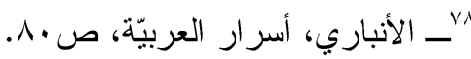

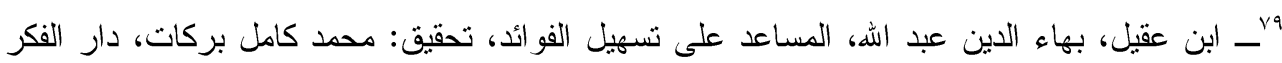

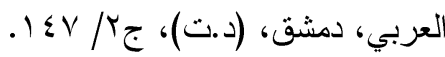

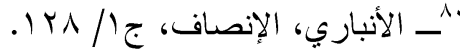

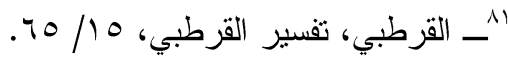

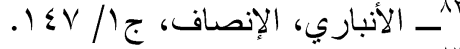

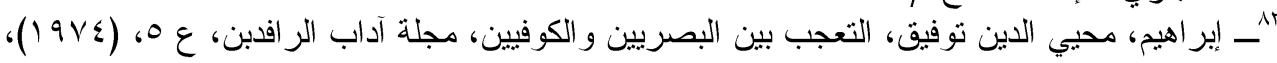

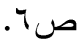

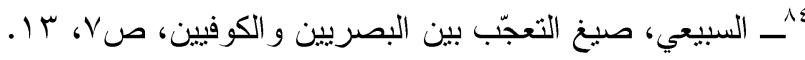

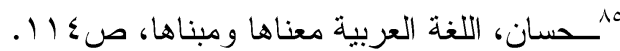

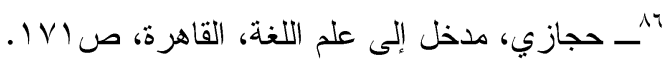

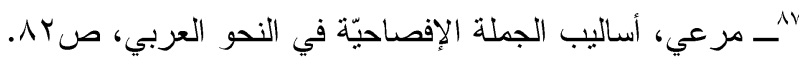

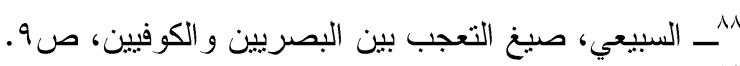

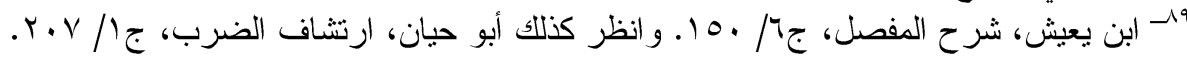

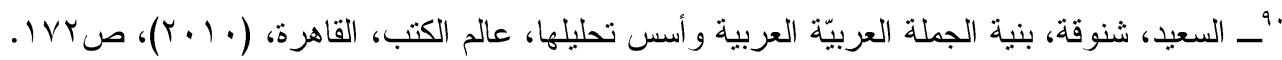

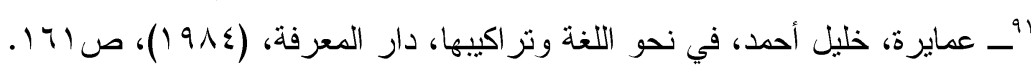

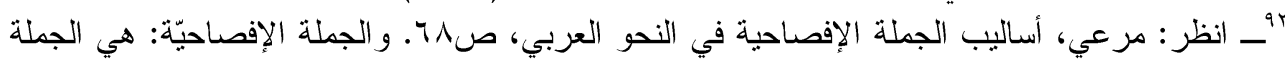

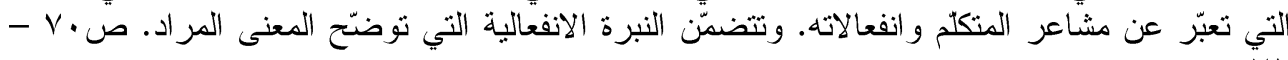

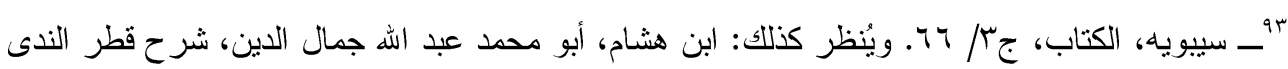

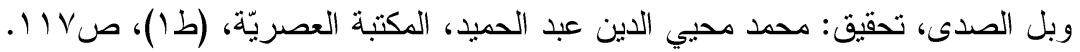




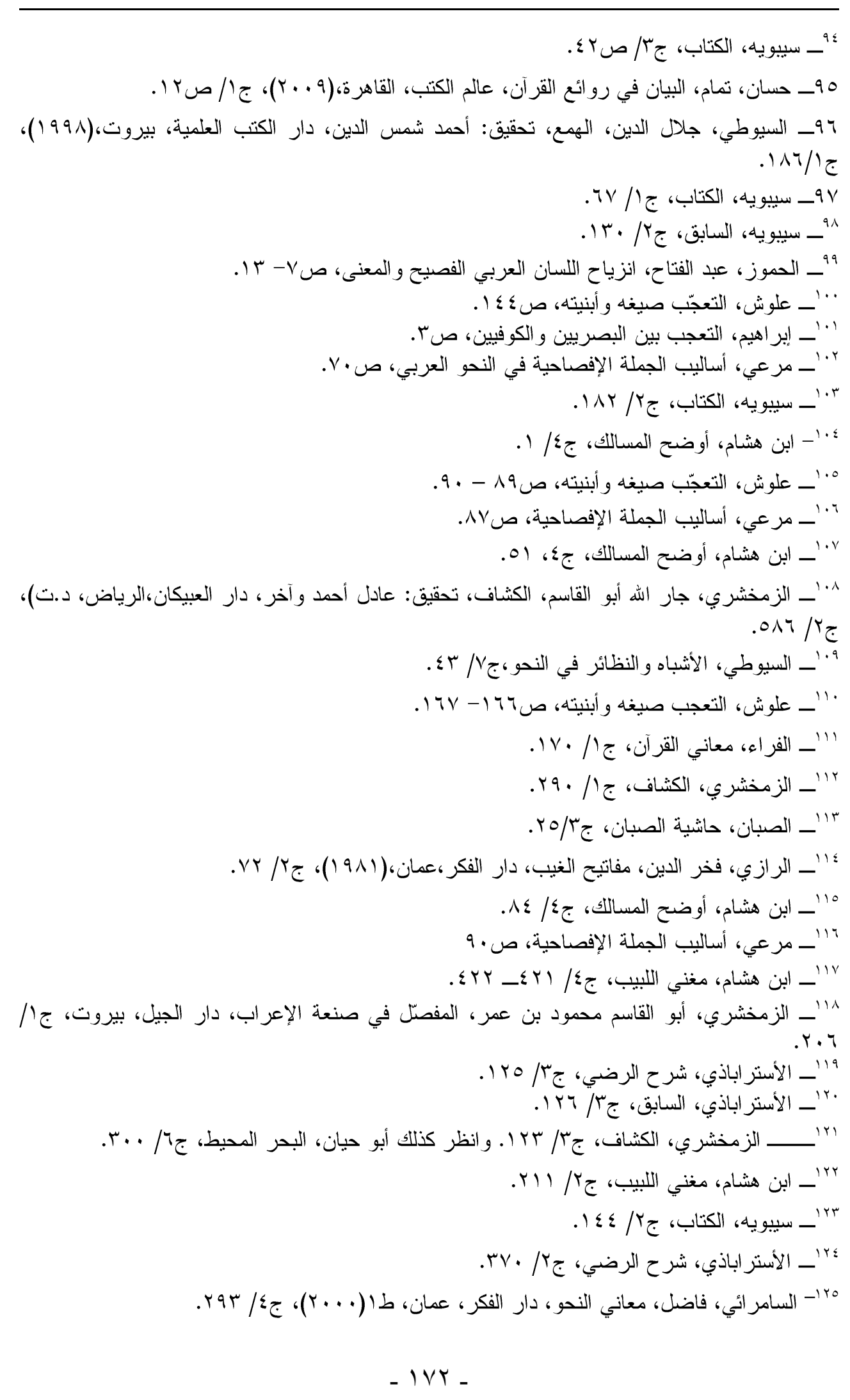




$$
\begin{aligned}
& \text { צ' - ابن هشام، مغني اللبيب، 1/ } 7 \text { • 1. }
\end{aligned}
$$

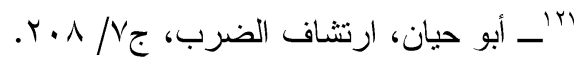

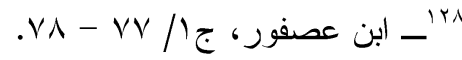

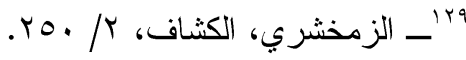

$$
\begin{aligned}
& \text { •" - أبو حيان، البحر المحيط، ج؟/ } 90 \text { - } 97 .
\end{aligned}
$$

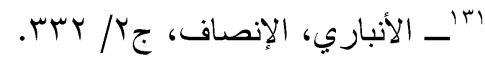

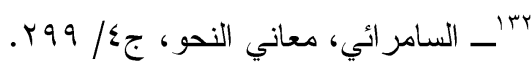

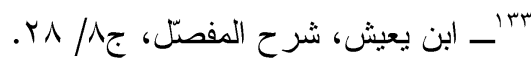

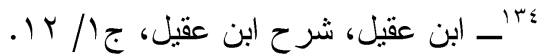

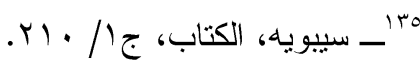

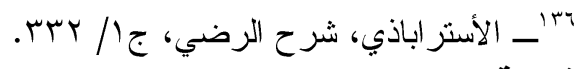

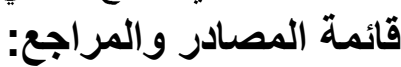

إ- إبر اهيم، محيي الدين توفيق، التعجب بين البصريين والكوفيين، مجلة آداب الر افدبن، عدده،

بـ الأزهري، خالا، بن عبد الله، شرح التصريح على التوضيح، تحقيق: محمد باسل، دار الكتب العلمية

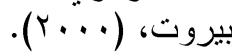

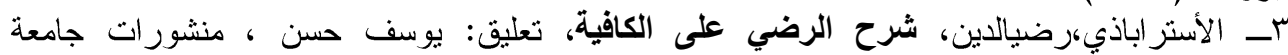

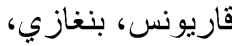

كــ الأنباري، عبد الرحمن بن محمد، أسرار العربيّة، در اسة: محمد حسين، دار الكتب العلميّة، بيروت، 0ـ الأنباري، عبد الرحمن بن محمد، الإتصاف في مسائل الخلاف، تحقيق: محمد محي الدين، مطبعة

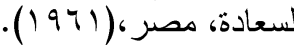
جــ الأبباري، عبد الرحمن بن محمد، نزهة الألباء في طبقات الأدباء، تحقيق: محمد أبو الفضل، دار

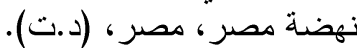

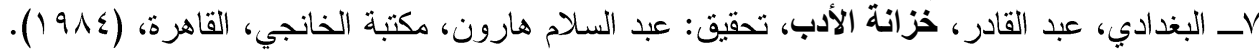

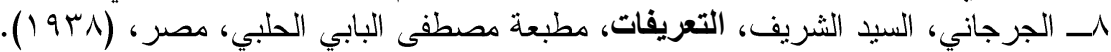

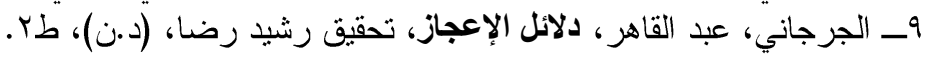

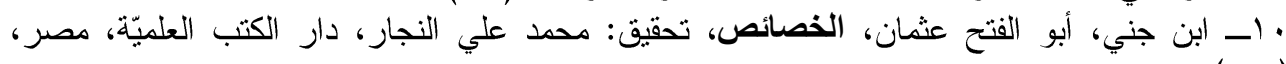

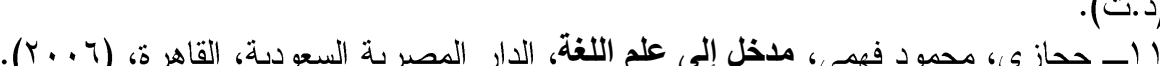

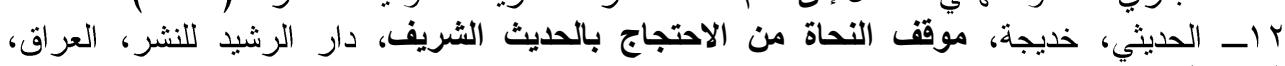

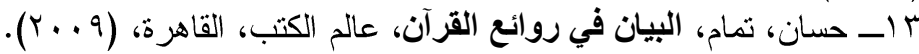

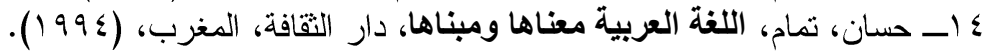

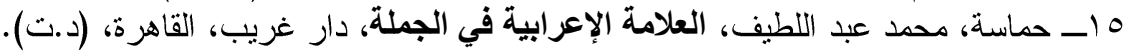

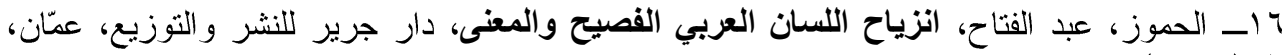


Vا_ـأبو حيان، محمد بن يوسف الأندلسي، البحر المحيط، تحقيق: عادل أحمد وآخرون، دار الكتب

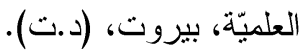

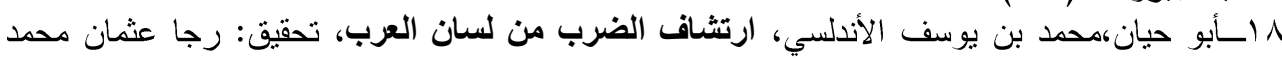

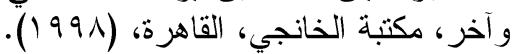

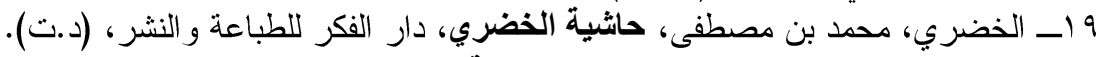

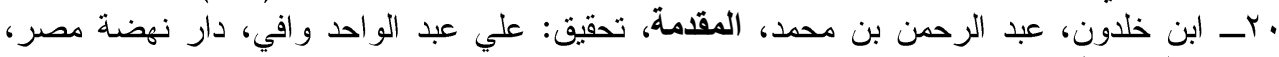

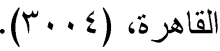
ابــ ابن خلكان، أبو العباس شمس الدين، وفيات الأعيان، تحقيق: إحسان عباس، دار صادر، بيروت،

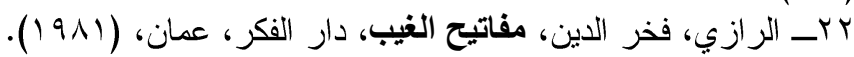

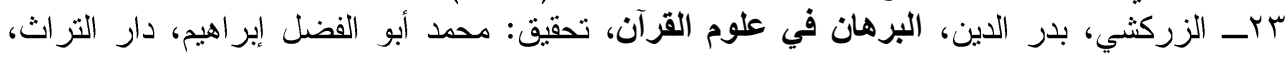

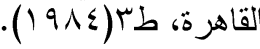
ع ז-ـ الزمخشري، أبو القاسم محمود بن عمر، الكثاف، تحقيق: عادل أحمد وآخر، دار العبيكان،

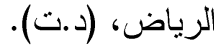

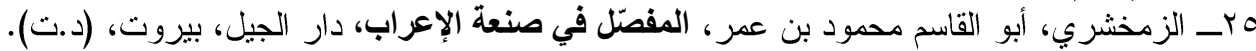

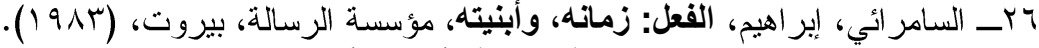

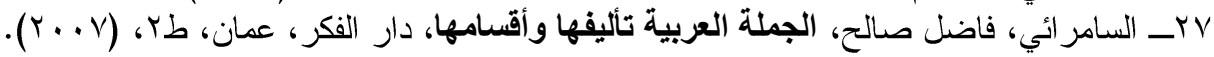

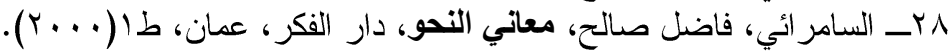

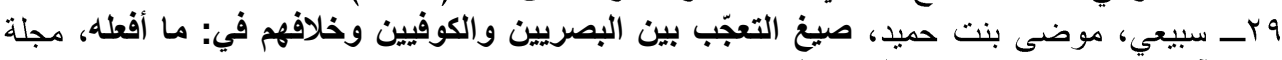

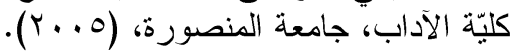

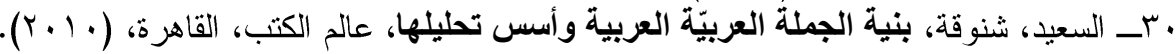

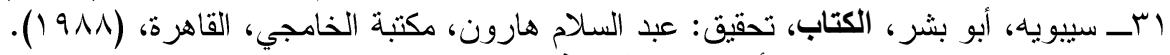

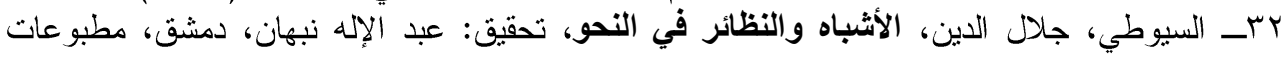
مجمع اللغة العزبية،(1910) (19). بrr_ السيوطي، جلال الدين، همع الهوامع، تحقيق: أحمد شمس الدين، دار الكتب العلمية، بيروت،

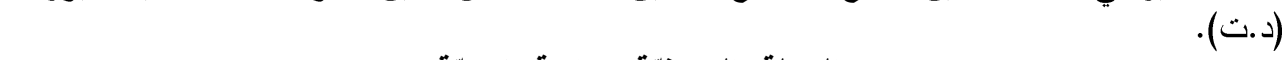
ع بـــ شنوف، نسرين عبد الله، الجملة الوصفيّة دراسة نحويّة، مركز دراسات الكوفة، جامعة

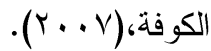

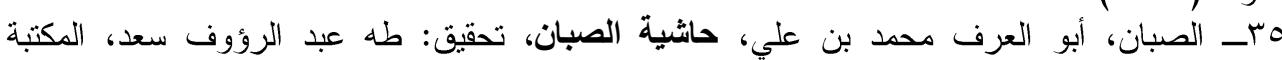

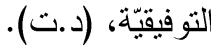
بـــ الطبري، أبو جعفر، ، التفسير الكبير، تحقيق: محمود محمد شاكر وآخر، مكتبة ابن تيمية، القاهرة،

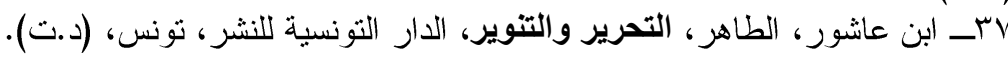

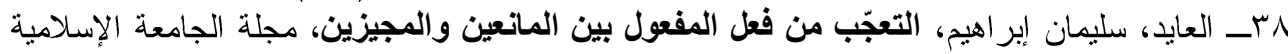

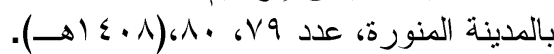

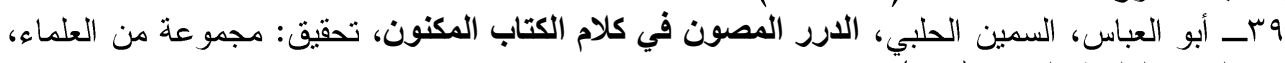

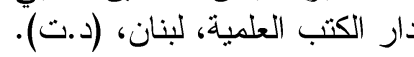
• ؛ــ ابن عبد ربه، أحمد بن محمد، العقد الفريد، تحقيق: محمد قديّة، دار الكتب العلميّة، بيروت،

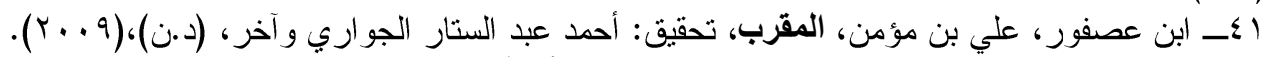

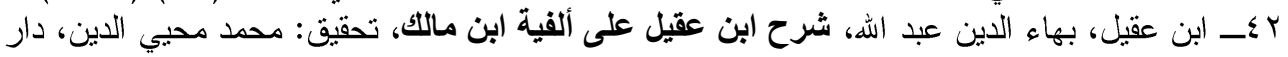

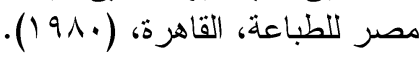
بـــ ابن عقيل، بهاء الدين عبد الله، المساعد على تسهيل الفوائد، تحقيق: محمد كامل بركات، دار الفكر

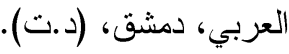




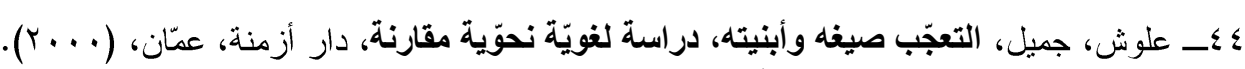

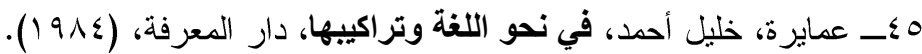

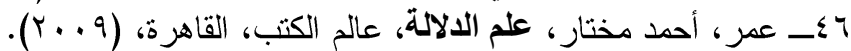

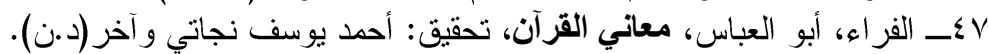

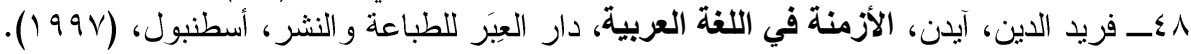

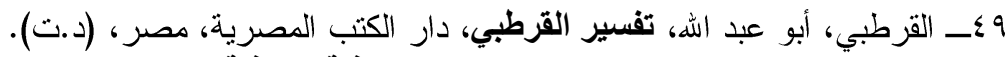

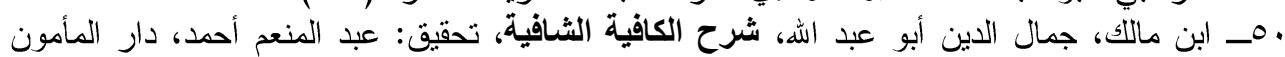

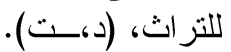

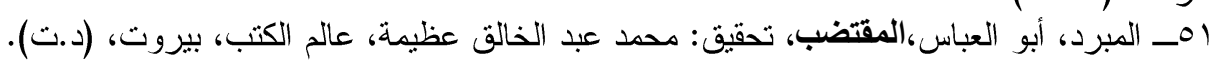

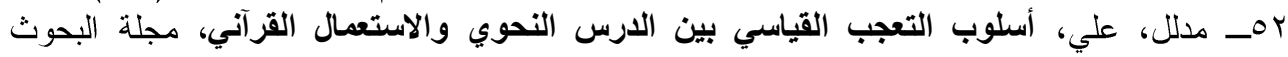

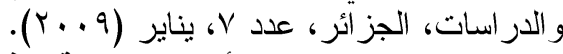

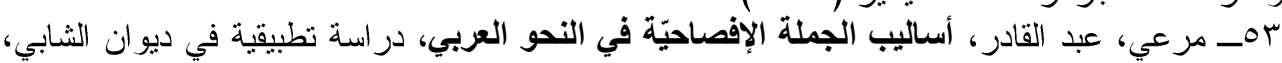

مؤسسة رام للتكنولوجيا، الأردن، (1990) (190).

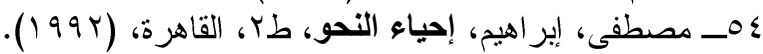

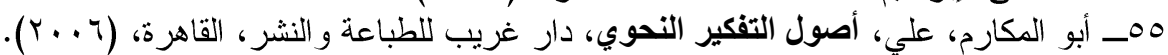

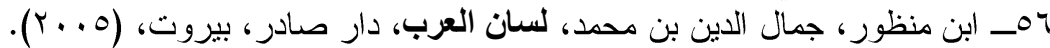

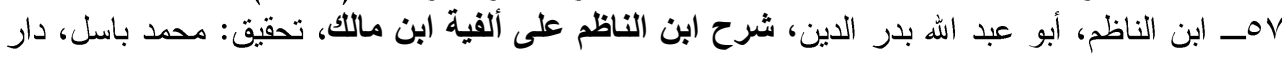

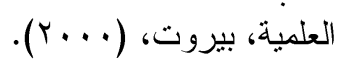

10ــ نبهان، عبد الإله، "مقترحات في تيسير بعض صيغ الإعراب"، ورقة مقدّمة في مؤتمر تيسير تعليم

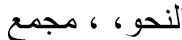

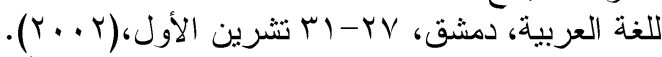

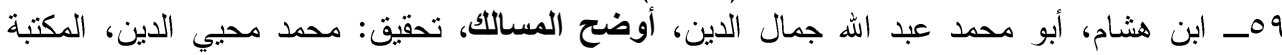

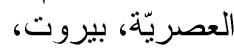

• Tــ ابن هشام، أبو محمد عبد اله جمال الدين، شرح قطر الندى ويل الصدى، تحقيق: محمد محيى الدين

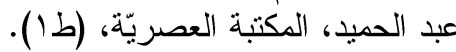
آ آــ ابن هشام، أبو محمد عبد الله جمال الدين، مغتي اللبيب، تحقيق: عبد اللطيف محمد الخطيب، (د.ن)،

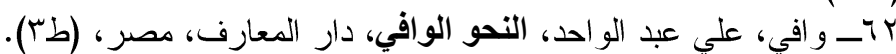

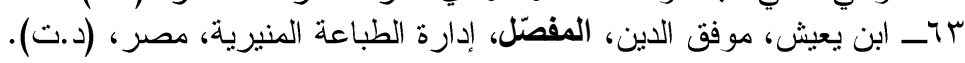

